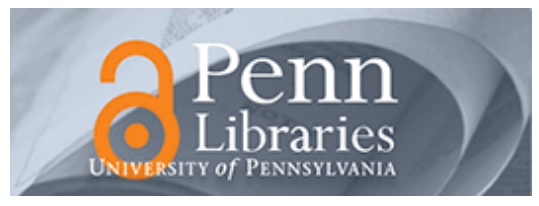

University of Pennsylvania

ScholarlyCommons

Management Papers

Wharton Faculty Research

3-2007

\title{
Business Model Design and the Performance of Entrepreneurial Firms
}

Christoph Zott

Raphael Amit

University of Pennsylvania

Follow this and additional works at: https://repository.upenn.edu/mgmt_papers

Part of the Business Administration, Management, and Operations Commons, and the Entrepreneurial and Small Business Operations Commons

\section{Recommended Citation}

Zott, C., \& Amit, R. (2007). Business Model Design and the Performance of Entrepreneurial Firms.

Organization Science, 18 (2), 181-199. http://dx.doi.org/10.1287/orsc.1060.0232

This paper is posted at ScholarlyCommons. https://repository.upenn.edu/mgmt_papers/130

For more information, please contact repository@pobox.upenn.edu. 


\title{
Business Model Design and the Performance of Entrepreneurial Firms
}

\author{
Abstract \\ We focus on the design of an organization's set of boundary-spanning transactions-business model \\ design-and ask how business model design affects the performance of entrepreneurial firms. By \\ extending and integrating theoretical perspectives that inform the study of boundary-spanning \\ organization design, we propose hypotheses about the impact of efficiency-centered and novelty-centered \\ business model design on the performance of entrepreneurial firms. To test these hypotheses, we \\ developed and analyzed a unique data set of 190 entrepreneurial firms that were publicly listed on U.S. \\ and European stock exchanges. The empirical results show that novelty-centered business model design \\ matters to the performance of entrepreneurial firms. Our analysis also shows that this positive \\ relationship is remarkably stable across time, even under varying environmental regimes. Additionally, we \\ find indications of potential diseconomies of scope in design; that is, entrepreneurs' attempts to \\ incorporate both efficiency- and novelty-centered design elements into their business models may be \\ counterproductive.
}

\section{Keywords}

organization design, new organizational forms, business model, design themes, organization performance, environmental munificence

Disciplines

Business Administration, Management, and Operations | Entrepreneurial and Small Business Operations 


\title{
Business Model Design and the Performance of Entrepreneurial Firms
}

\author{
By \\ Christoph Zott* \\ and \\ Raphael Amit**
}

December 5, 2005

Both authors contributed equally to this article. Christoph Zott gratefully acknowledges financial support from the Alliance Center for Global Research \& Development, and the Rudolf and Valeria Maag Fellowship in Entrepreneurship. Raffi Amit acknowledges generous financial support of the Wharton e-business initiative (a unit of the Mack Center for Technological Innovation at the Wharton School), and the Robert B. Goergen Chair in Entrepreneurship at the Wharton School. Both authors thank Iwona Bancerek, Amee Kamdar, and Jenny Koelle for their research assistance. We are grateful to Rich Burton and to two anonymous reviewers for helpful comments. For insightful comments during the development of this study, we would like to thank Eric Bradlow, Hubert Gatignon, Lorin Hitt, Ha Hoang, Quy Huy, Aba Krieger, Anita McGahan, Werner Reinartz, Nicolaj Siggelkow, Belen Villalonga, and seminar participants at Washington University in St. Louis and at the Wharton School.

\footnotetext{
* Associate Professor of Entrepreneurship at INSEAD, Boulevard de Constance, 77305 Fontainebleau Cedex, France. Telephone: 33160724364 - Fax: 33160724223 E-mail: christoph.zott@insead.edu

** The Wharton School, University of Pennsylvania, 3620 Locust Walk, Philadelphia, PA 19104-6370 - Telephone: (215) 898-7731 - Fax: (215) 573-7189 - E-Mail: amit@wharton.upenn.edu
}

A working paper in the INSEAD Working Paper Series is intended as a means whereby a faculty researcher's thoughts and findings may be communicated to interested readers. The paper should be considered preliminary in nature and may require revision.

Printed at INSEAD, Fontainebleau, France. Kindly do not reproduce or circulate without permission. 


\title{
Business Model Design and the Performance of Entrepreneurial Firms
}

\begin{abstract}
We focus on a particular organization design issue - namely, the design of an organization's set of boundary-spanning transactions - which we refer to as business model design, and ask how business model design affects the performance of entrepreneurial firms. Specifically, by extending and integrating theoretical perespectives that inform the study of boundary-spanning organization design, we propose hypotheses about the impact of efficiency-centered and novelty-centered business model design on the performance of entrepreneurial firms. To test these hypotheses, we developed and analyzed a unique data set of 190 entrepreneurial firms that were publicly listed on U.S. and European stock exchanges. The empirical results show that novelty-centered business model design matters to the performance of entrepreneurial firms. Our analysis also shows that this positive relationship is remarkably stable across time, even under varying environmental regimes. As well, we find indications of potential diseconomies of scope in design; that is, entrepreneurs' attempts to incorporate both efficiency- and novelty-centered design elements into their business models may be counterproductive.
\end{abstract}

Keywords: Organization design, new organizational forms, business model, design themes, organization performance, environmental munificence. 


\section{Business Model Design and the Performance of Entrepreneurial Firms}

An organization is a goal-directed social entity that consists of deliberately structured and coordinated activity systems; it can be conceived of as an open system that interacts with its environment (Thompson 1967). Its subsystems can be classified either "internal" or "boundaryspanning" (Daft 2004). Substantial research on organization design has focused on internal design issues such as centralization, span of control, personnel ratios, and lines of authority (e.g., Nystrom and Starbuck 1981). Some scholars, however, have observed that organizations are increasingly "experimenting with their governance of transactions, that is, adopting new ways of structuring their boundaries" (Foss 2002, p. 1). Consequently, a growing body of work on organizational forms has gradually shifted attention from internal design toward modes of organizing and managing transactions with the firm's environment (e.g., Ilinitch, D'Aveni and Lewin 1996, Lewin and Volbverda 1999, Miles and Snow 1986, Romanelli 1991). While this body of research has enhanced our understanding of how managers and entrepreneurs set organizational boundaries, important questions remain open. For example, how can the design of an organization's set of boundaryspanning transactions be described and measured, and what do we know about the performance implications of different designs?

These questions provide the point of departure for this study. Recent advances in communication and information technologies, such as the emergence of the Internet, and the rapid decline in computing and communication costs have accentuated the possibilities for the design of new boundary-spanning organizational forms (Daft and Lewin 1993, Foss 2002, Ilinitch et al. 1996). ${ }^{1}$ Indeed, these developments have opened new horizons for the design of business models by enabling firms to change fundamentally the way they organize and engage in economic exchanges, both within and across firm and industry boundaries (Mendelson 2000). According to Brynjolfsson and Hitt (2004), information technologies have changed fundamentally the ways in which firms interact with suppliers as well as customers. This emerging stream of work on boundary-spanning designs complements a large body of literature that points to the links between internal organization design 
issues, such as the degree of decentralization, the structure of incentives, and the implications on productivity for investment in information technologies (e.g., see Bresnahan, Brynjolfsson and Hitt 2002, or Ichniowski, Kochan, Levine, Olson and Strauss 1996). This paper builds on the shift in perspective from viewing organization form as a complement to IT investments towards viewing IT as an enabler of boundary-spanning organizational design.

Specifically, in this paper we refer to the design of an organization's boundary-spanning transactions as business model design, and we ask: How can business model design be measured, and how does it affect firm performance? Along the lines of Amit and Zott (2001, p. 511), we formally define the business model as depicting "the content, structure, and governance of transactions designed so as to create value through the exploitation of business opportunities." That is, a business model elucidates how an organization is linked to, and how it engages in economic exchanges with, external stakeholders in order to create value for all exchange partners.

Designing the business model is a salient issue for entrepreneurisl firms who are less constrained by path dependencies and inertia than more established firms (Stinchcombe 1965). Following Bhide (2000) we define entrepreneurial firms as relatively young organizations that have the potential of attaining significant size and profitability. Their performance often critically depends on boundary-spanning organizational arrangements (Hite and Hesterly 2001). One of the central design tasks of entrepreneurs is, consequently, to delineate the ways in which their new businesses transact with suppliers, customers, and partners. As Ireland et al. (2001, p.53) note, entrepreneurs often "try to find fundamentally new ways of doing business that will disrupt an industry's existing competitive rules, leading to the development of new business models." For example, Christensen (2001) highlighted the shift in the locus of profitability in the computer industry as companies, such as Dell, pioneered non-integrated and flexible business models in which production and distribution were organized in novel ways. Even when entrepreneurial firms replicate the business models of existing organizations (Aldrich 1999), they may have to adapt these designs to their own environment (McGrath and MacMillan 2000).

\footnotetext{
According to Brynjolfsson and Hitt (2004), the costs of automated information processing have fallen more than $99.9 \%$ since the 1960 s.
} 
Although recent work in entrepreneurship and organization theory has begun to address the important role of design in the entrepreneurship process (Hargadorn and Douglas 2001, Romme 2003, Van de Ven, Hudson and Schroeder 1984), relatively little is known about the specific trade-offs and performance implications of business model design, which can be far-reaching. For example, Hargadorn and Douglas (2001, p. 494) attribute the failure of Prodigy, an on-line service in which investors had invested $\$ 600$ million, to the mismatch between the design of its business model and customer needs.

In this paper we identify two critical dimensions of business model design, which we denote as "efficiency-centered" and "novelty-centered" design themes. Anchoring our reasoning in the transaction cost perspective (Milgrom and Roberts 1992, Williamson 1975) and in Schumpeter's theory of innovation (Schumpeter 1934), we offer hypotheses about the impact of business model design themes on the performance of the focal firm, taking into consideration the potentially moderating role of the environment. Efficiency-centered business model design aims at reducing transaction costs for all transaction participants, while novelty-centered business model design refers to new ways of conducting economic exchanges among various participants. These design themes are neither orthogonal (for instance, novel design elements may engender lower transaction costs), nor are they mutually exclusive: Both may be present in the design of any given business model. Moreover, the design themes are not exhaustive. Business models may be characterized by other value-creation themes. These include "lock-in," which refers to designs that attempt to retain stakeholders, and "complementarities," which refer to designs that emphasize the bundling of goods, activities, resources, or technologies (Amit and Zott 2001). We focus herein on efficiency- and noveltycentered designs in the interest of building and testing parsimonious theory.

To test our hypotheses, we have developed a unique data set that contains detailed information about the business models of 190 entrepreneurial firms that were listed on a public exchange between 1996 and 2000. We measure each business model design theme as a variable at a particular point in time, and we regress these variables on a range of performance measures. Overall, we find that business model design matters to the performance of entrepreneurial firms. Our most robust finding relates to the positive association between novelty-centered business model design and 
firm performance. Our analysis shows that this positive relationship is remarkably stable across time, even under varying environmental regimes. Our results also indicate that entrepreneurs' attempts to design both efficiency- and novelty-centered business models may be counterproductive.

This paper builds on and extends earlier work that has considered business models in the context of organizational performance. Focusing primarily on the impact of network effects on the stock market value of e-commerce firms, Rajgopal, Venkatachalam and Kotha (2003) examine how network effects interact with the firm's business model, measured as a categorical variable (i.e., content provider, portal, financial services, e-tailer, or auction site). In our analysis, we focus primarily on the design of the business model (rather than on network effects), and on its direct impact on firm performance, both theorerically as well as empirically; our continuous measures of business model design apply to a broad range of firms. Using an event study methodology and a sample of four firms which use the Internet to engage in transactions with external stakeholders, Filson (2004) studies the impact on firm value of the competitive strategies of Amazon.com, Barnesandnoble.com, CDNow, and N2K. We, too, focus on firms that derive at least some of their revenue through transactions that are exectuted on the Internet. However, we examine in detail the impact of business model design, distinct from the competitive strategy of a firm (Zott and Amit 2005), on firm value. Moreover, we look at a large sample of firms in the U.S. and Europe.

This study, then, attempts to make several contributions to the organization design literature. First, we refine concepts and measures for examining the design of a firm's business model. The importance of research on transaction designs as new organizational forms has been recognized in earlier studies, (e.g., Foss 2002, Rindova and Kotha 2001). We contribute to this literature through the development of granulated concepts for operationalizing and measuring business model designs. Second, we provide a theoretical extension of the transaction costs perspective and of Schumpeter's theory of innovation. By integrating into these theories bargaining theory, we develop the performance implications of business model design under varying regimes of environmental munificence, specifically for entrepreneurial firms whose transactions are enabled by information and communication technologies. There is little prior theory on this issue. Third, drawing on a large and a unique hand-collected data set about business model design themes, we test the linkage between these 
design themes and focal firm performance. Although we we build on earlier studies that examine how business models are linked to firm performance (e.g, Rajgopal et al. 2003), we believe that this is the first study to operationalize, measure, and test the performance consequences of business model design themes. Further, by highlighting the pivotal role that business model design plays in the performance of entrepreneurial firms our study contributes to the entrepreneurship literature.

In summary, in this paper we argue theoretically and show empirically that the business model is a useful unit of analysis for research on boundary-spanning organization design, as well as a locus of innovation that has hitherto been largely overlooked by entrepreneurship research. Rindova and Kotha (2001, p. 1277) have pointed out the need for "a broader and more dynamic understanding of [organizational] form, in which it is viewed as a flexible arrangement of resources and structures configured to generate a stream of value-creating products and services." The concept of the business model fulfills these requirements, and thus can potentially help advance the emerging body of research on new organizational forms.

The remainder of the paper is organized as follows: The subsequent section presents our theory and hypotheses. It is followed by sections describing our data and methods and our results. We conclude with a discussion of our findings and implications of our study for future research.

\section{THEORY AND HYPOTHESES DEVELOPMENT}

\section{Business Model Design Themes}

To develop measures of business model design, configuration theory provides a useful starting point because it considers holistic configurations, or gestalts, of design elements (Miles and Snow 1978). Configurations are constellations of design elements that commonly occur together because their interdependence makes them fall into patterns (Meyer, Tsui and Hinings 1993). The design elements of a business model are the content, structure, and governance of transactions. In this paper, we follow Miller's (1996) suggestion to view configuration as a variable rather than as a deviation from an ideal type. Miller states that, "Configuration... can be defined as the degree to which an organization's elements are orchestrated and connected by a single theme" (Miller 1996, p. 509). 
The relevant question then is the following: What are the common design themes that orchestrate and connect a business model's elements? Miller (1996) mentions innovation and efficiency as possible design themes. This choice appears particularly appropriate for the study of business models adopted by entrepreneurial firms as the two themes reflect fundamental alternatives for entrepreneurs to create value under uncertainty. Novelty and efficiency play important roles for the emergence of new organizations because entrepreneurs can create new designs and/or reproduce and copy existing ones (Aldrich 1999). Imitation-based approaches towards business creation are often associated with an emphasis on lower costs, i.e., increased efficiency (Zott 2003). Since these themes are not mutually exclusive, any given business model design can be novel and efficient at the same time.

\section{Business Model Design, Firm Performance, and the Moderating Role of the Environment}

We hypothesize that the design of an entrepreneurial firm's business model, which is centered specifically on the themes of novelty and/or efficiency, is associated with the performance of that firm. This association can be broken down into two effects: One relies on the total value-creation potential of the business model design, and the second considers the impact of business model design on the firm's ability to appropriate the value that its business model creates.

Business models can create value by enhancing the customers' willingness to pay or by decreasing suppliers' and partners' opportunity costs, for example, through improved transaction efficiency. The total value created by a business model is also a function of the competitive alternatives, in other words, the market power of the focal firm's business model vis-à-vis rival business models. The total value created is the value created for all business model stakeholders (focal firm, customers, suppliers, and other exchange partners). It is the upper limit for the value that can be captured by the focal firm (Brandenburger and Stuart 1996).

An important question emerges: How does business model design influence the competing claims to total value created by different stakeholders to the business model? Drawing on Porter (1980) and Kogut (2000), we reason that the value eventually appropriated by the focal firm hinges on the bargaining power of the focal firm relative to other business model stakeholders. Thus, the overall effect of the business model design theme on firm performance is partly determined by the bargaining 
position of the focal firm. This reasoning suggests a positive association between the design of the business model and the performance of the focal firm if, for a given level of competition, the focal firm's business model design creates value, and its bargaining power relative to other business model stakeholders does not decrease.

Environmental conditions seem important to consider as moderators of the hypothesized relationship between business model design and the performance of an entrepreneurial firm (McArthur and Nystrom 1991). Munificence, dynamism, and complexity are all important dimensions of the environment that could be examined (Dess and Beard 1984). In this paper, we focus on munificence, because it captures the availability of resources, which is a key challenge for entrepreneurial firms. According to Randolph and Dess (1984) and McArthur and Nystrom (1991), munificence influences the survival and growth of existing companies, as well as the ability of new firms to enter the market. The use of munificence as a focal dimension of environmental uncertainty derives from a resource-dependence view of organizations that treats environments as arenas in which all compete for resources (Pfeffer and Salancik 1978, Aldrich 1979). This perspective seems particularly relevant for entrepreneurial firms, which depend critically on external resources, and, in particular, on the receptivity of capital and product markets to innovative activity.

Consistent with these arguments, and building on the work of Aldrich (1979), Dess and Beard (1984), and Tushman and Anderson (1986), we define munificence as the extent to which the environment supports growth. Specifically, in this paper, munificence refers to the scarcity or abundance of critical resources required to create and implement business model designs. As we argue below, the performance prospects of ventures with novelty- and/or efficiency-centered business model designs may vary with the availability and costs of resources that entrepreneurs can access.

\section{Novelty-centered Business Model Design and Performance}

At the heart of entrepreneurship, and the design of new boundary-spanning organizational designs, lies the act of innovation, which can be defined as "employing existing resources in a different way, in doing new things with them, irrespective of whether those resources increase or not" (Schumpeter 1934, p. 68). This Schumpeterian logic of innovation through recombination of resources is consistent with the emphasis of this paper on entrepreneurial firms that rely on new 
technologies to transact with external stakeholders. For example, a firm could use the Internet to reconfigure the ways in which its own competencies are linked with those of its customers (Von Hippel and Katz 2002). The essence of novelty-centered business model design is the conceptualization and adoption of new ways of conducting economic exchanges, which can be achieved, for example, by connecting previously unconnected parties, by linking transaction participants in new ways, or by designing new transaction mechanisms. Business model innovation may complement innovation in products and services, methods of production, distribution or marketing, and markets (Schumpeter 1934). A novel business model either creates a new market eBay is a case in point - or innovates transactions in existing markets - Priceline.com and Dell are cases in point. Dell, for instance, implemented a customer-driven build-to-order business model, which replaced the traditional build-to-stock model of selling computers through retail stores (Brynjolfsson and Hitt, 2004).

Thus, the business model may serve not only to exploit an opportunity for wealth creation, but its design may also be part of the opportunity development process in and of itself. The entrepreneuras-designer can co-create opportunities, for example, by drawing on new information and communication technologies to bridge factor and product markets in new ways.

Business model innovation may give rise to entrepreneurial rents (Rumelt 1987). These monopoly-type rents may accrue to business model stakeholders between the time an innovation is introduced and the time it is diffused. Although we expect a positive primary effect of noveltycentered business model design on the performance of entrepreneurial firms, entrepreneurial rents may accrue to all stakeholders in the business model. Thus, in order to predict the overall effect of novelty-centered business model design on the performance of the focal entrepreneurial firm, we must also consider the effect of novelty-centered design on the ability of that firm to appropriate the value that its business model generates. This ability depends on such factors as (i) the switching costs of other business model stakeholders; (ii) the firm's ability to control information, (iii) its ability to take unified action vis-à-vis stakeholders, and (iv) the replacement costs of other business model stakeholders (Coff 1999). We suggest that, on average, an increase in business model novelty will not decrease the focal entrepreneurial firm's ex-post bargaining power relative to other business model 
stakeholders. The focal firm is the innovator, and its business model is the locus of innovation. The higher the degree of business model novelty, the higher the switching costs for the focal firm's customers, suppliers and partners, as alternatives to doing business with the focal firm may not be readily available, whereas determinants (ii)-(iv) of the focal firm's bargaining power are unlikely to be systematically affected in one direction or the other; hence, the focal firm will have greater relative bargaining power vis-à-vis these parties. Therefore, considering both the positive effect of noveltycentered business model design both on total value created and on the ability of the focal firm to capture that value, we expect a positive effect of novelty-centered business model design on the performance of an entrepreneurial firm.

Hypothesis 1: The more novelty-centered an entrepreneurial firm's business model design, the higher is the firm's performance.

In periods of high resource availability, novelty-centered business model design will matter more to performance than in periods of resource scarcity. In times of high resource munificence, entrepreneurs have easier access to the resources necessary to support and implement their business model innovations, such as investments in complementary assets. In other words, in environments characterized by high resource munificence, the advantages derived from novelty-centered business models are accentuated, while our arguments about the bargaining power of firms with novel business models continue to hold. Entrepreneurial firms with novelty-centered business model designs are poised to take advantage of the greater willingness of customers to spend, and they will not suffer a decrease in their aggregate bargaining power vis-à-vis other business model stakeholders. Thus, novel business model design is more distinctly associated with higher firm performance when resources are abundant than when they are scarce. 
Hypothesis 2: In environments characterized by high resource munificence, the positive association between novelty-centered design and the performance of the entrepreneurial firm will be higher than in environments with low resource munificence.

\section{Efficiency-centered Business Model Design and Performance}

An alternative way for entrepreneurs to create wealth is to replicate existing offerings, organizations, or business models. In other words, entrepreneurs may choose to imitate rather than innovate - to do similar things as established organizations, yet do these things in a more efficient way (Aldrich 1999, Zott 2003). To examine the performance implications of efficiency-centered business models, we build on the transaction cost perspective (Milgrom and Roberts 1992, Williamson, 1975, 1983). This appears appropriate because this perspective, like the business model construct, refers to the design of economic transactions. According to Williamson (1983), exchange attributes, including information asymmetry and complexity, determine that transactions will be organized into markets or hierarchies in ways that minimize transaction costs and maximize performance (Poppo and Zenger 1998). Researchers generally assume that economic actors whose transactions are not aligned with appropriate governance structures are "more likely to display poor financial performance ... than those whose transactions are properly aligned" (Silverman 2001, p. 484). Poppo and Zenger (1998) have explicitly modeled the performance implications of the transaction cost perspective. And Milgrom and Roberts (1992) have elaborated on the effect that both transaction costs, in the form of coordination, and motivation costs have on firm performance. These studies suggest that there is an important direct relationship between the design of transactions and firm performance.

Efficiency-centered design refers to the measures that firms may take to achieve transaction efficiency through their business models. The essence of an efficiency-centered business model is the reduction of transaction costs. This reduction can derive from the attenuation of uncertainty, complexity, or information asymmetry (Williamson 1975), as well as from reduced coordination costs and transaction risk (Clemons and Row 1992, Milgrom and Roberts 1992). The order-tracking feature in Amazon's business model, for example, is aimed at enhancing transaction transparency and, therefore, constitutes an efficiency-centered design element. It reduces the cost of providing 
information to the logistics company, and it induces more customers to check on their packages than would do if they did not have access to the feature (Brynjolfsson and Hitt, 2004). Other efficiencycentered design elements are intended to increase the reliability and simplicity of transactions, reduce the asymmetry of information among transaction participants, speed up transactions, enable demand aggregation, reduce inventory, provide for transaction scalability, or reduce the direct and indirect costs of transactions, etc. Consider Baxter ASAP, which lets hospitals electronically order supplies directly from wholesalers. By reallocating its saved resources (the costs of data entry), the company was able to offer additional value-adding services to its customers (Brynjolfsson and Hitt 2004). Consequently, we expect a positive primary effect on firm performance of adopting an efficiencycentered business model design.

In order to predict the overall effect of an efficiency-centered business model design on the performance of an entrepreneurial firm, however, we must also consider the effect of efficiencycentered design on the ability of the firm to appropriate the value that its business model generates. As in the case of novelty centered business model designs, this ability depends on (i) the switching costs incurred by other business model stakeholders, (ii) the firm's ability to control information flows, (iii) its ability to take unified action vis-à-vis stakeholders, and (iv) the replacement costs of other business model stakeholders (Coff 1999). One aspect of efficiency-centered design is that it enables better information flow among stakeholders and reduces information asymmetries among the parties, thus limiting the control over information (ii) that any stakeholder can have. It also reduces transaction complexity by streamlining transactions and implementing deep linkages among businessmodel stakeholders that often do not require transaction-specific investments, such as the use of web services. These effects are likely to affect the switching costs (i) for all parties in the same direction so that, in the aggregate, the balance of power will not shift. Moreover, it should be noted that reducing direct transaction costs (e.g., search, transportation, and coordination costs) increases the pool of potential customers, as well as partners and suppliers, and thus implies a consequent reduction in the cost to the focal firm of replacing such stakeholders (iii). These arguments suggest that, on balance, a more pronounced efficiency-centered business model design does not decrease the focal firm's 
bargaining power relative to other business model stakeholders. We therefore expect a positive main effect of efficiency-centered business model design on the performance of an entrepreneurial firm.

Hypothesis 3: The more efficiency-centered an entrepreneurial firm's business model design, the higher is the firm's performance.

When resources are scarce and not readily available to entrepreneurs, efficiency-centered business model design assumes greater importance as a differentiating factor among business models than in periods of resource munificence. In tough economic environments, consumers and businesses spend and invest less; cost savings become relatively more important as a driver of value creation. Entrepreneurial firms are more volatile than established organizations (Stinchcombe, 1965); therefore, they are quite sensitive to such changes. Conversely, during times of high environmental munificence, total value can be enhanced, for example, by tapping additional revenue streams. In other words, in environments characterized by low resource munificence, the advantages derived from reduced transaction costs are accentuated, while our arguments about the bargaining power of firms with efficient business models continue to hold. Entrepreneurial firms with efficiency-centered business model designs are poised to take advantage of transaction cost savings, and they will not suffer a decrease in their aggregate bargaining power vis-à-vis other business model stakeholders. Thus, efficient business model design will be more distinctly associated with higher performance of an entrepreneurial firm when resources are scarce than when they are abundant.

Hypothesis 4: In environments characterized by low resource munificence, the positive association between efficiency-centered design and the performance of the entrepreneurial firm will be greater than in environments with high resource munificence.

\section{Interaction between Novelty- and Efficiency-centered Business Model Design and Performance}

Do the above arguments imply that entrepreneurs should embrace both efficiency-centered and novelty-centered business model deisgns? Indeed, the need for balancing design elements has been recognized by researchers who highlight the benefits for entrepreneurs of reconciling distinct aspects of design, such as the familiar and the unfamiliar (Hargadorn and Douglas 2001), conformity and differentiation (Deephouse 1999), and reliability and distinctiveness (Zott and Huy 2005). Achieving such balance can help entrepreneurs build much-needed legitimacy, which can be 
considered a pre-requisite for venture growth and performance (Zimmerman and Zeitz 2002). This line of reasoning suggests that novelty and efficiency can be complementary design themes, and thus the effect of their interaction on performance could be positive. First, increasing the degree of novelty of a business model may enhance the return on efficiency-centered design. As previously discussed, novelty-centered business model design makes a business model more distinctive, and this may result in increased switching costs for other business model stakeholders because of fewer comparable alternatives. Hence, by emphasizing business model novelty, the focal firm may be better positioned to appropriate some of the value it creates through increased efficiency. Second, increasing the emphasis on efficiency-centered design may enhance the return on novelty. Novel business models that are also designed for efficiency may appeal to a wider range of customers (i.e., not only to those who are intrigued by its novel elements, but also to those who appreciate lower transaction and coordination costs). Thus, by simultaneously emphasizing efficiency and novelty as design themes, the entrepreneur may be able to create even more value than through either novelty-centered or efficiency-centered business model design alone.

Hypothesis 5: The more novelty-centered and efficiency-centered the business model design, the higher the performance of the entrepreneurial firm.

However, another line of reasoning suggests that attempts by entrepreneurs to design their business models concurrently for higher efficiency and greater novelty may instead adversely affect their firm's performance. Embracing two major design themes in parallel could lead to suboptimal resource allocation. Given the limited resources available to entrepreneurial firms, entrepreneurs who try to achieve too much at once may find that they are not getting adequate returns on their design efforts and investments. This is because a lack of focus may confuse market participants, undermine the venture's legitimacy, create technological and organizational problems, and lead to higher costs. Furthermore, it has been argued that a firm that gets stuck between innovation and imitation - or, analogously, between novelty and efficiency design themes - may perform poorly because it misses out on the opportunity to learn to become an even more skillful innovator or imitator (Zott 2003). In summary, there might be diseconomies of scope in design resulting from bundling novel and efficient design elements. 
Hypothesis 6: The more novelty-centered and efficiency-centered the business model design, the lower the performance of the entrepreneurial firm.

\section{DATA AND METHODS}

\section{Sample}

To test our hypotheses on the boundary-spanning organizational designs of entrepreneurial firms, we studied the business models of firms that derived all or part of their revenues from transactions conducted over the Internet. We presume these firms are likely to experiment with, and take advantage of, the possibilities that advanced information and communication technologies offer for the design of business models. We examined the business models of firms that had gone public in Europe or in the US between April 1996 and May 2000. Our sample selection strategy enabled us to create a data set of 362 relatively young, entrepreneurial firms and their business models, from which we randomly sampled 201. Poor data quality and limited data availability forced us to drop 11 firms from the sample, which left us with a final sample size of 190 . We considered public companies both to ensure the availability of data and because data collection from initial public offering documents is an acknowledged method for studying entrepreneurial firms (e.g., Dowling and McGee 1994). Concerns about survival bias (i.e., novelty-centered business model design could be positively correlated with firm performance because novel business models that did not achieve a particular level of success did not make it to the IPO stage) are mitigated by the fact that during the sampling period, the threshold for becoming a public company was relatively low, which resulted in listing very young and immature companies. As a result, many of the firms in our sample still faced highly uncertain prospects at the time they went public (Lieberman 2005). Indeed, when we investigated the fate of these firms in June 2004, we found that 107 of our 190 
sample firms ( $56 \%$ ) had been delisted: 20 had gone bankrupt, 68 had been acquired, 8 had been merged, and 11 had been taken private. ${ }^{2}$

\section{Data Collection}

For each business model design theme, we built composite scales and identified and measured relevant items in a survey instrument (see Appendix A). The surveying process proceeded in five stages: (1) development of the survey instrument, (2) development of measurement scales, (3) pretesting of the survey, (4) development of an on-line web interface and of a central database, and (5) data collection.

Following the increasing use of panelists in management research (e.g., Iansiti and Clark 1994, Lee, Smith and Grimm 2003, MacCormack, Verganti and Iansiti 2001), we hired 11 part- or full-time research assistants (primarily MBA students), and trained them as raters to fill in the survey instrument for assigned sample companies. We carefully selected our raters from a larger pool of applicants by interviewing them and asking them to submit an abbreviated test survey on a randomly chosen, sample company to display their understanding of Internet-based business models. After choosing the most qualified candidates, we trained them in data collection and data analysis. In addition, raters were provided with written guidelines on how to properly address survey items. Moreover, each rater was assigned to one of two project managers, who reviewed completed surveys for internal consistency and completeness, but not for the accuracy of each individual measurement. On average, it took a rater about two and a half days to collect data on a given business model, to

2 There are many studies that examine a range of issues which relate to the conduct and performance of ecommerce firms that became publicly listed corporations during the late $1990 \mathrm{~s}$. For example, using event study methodology, Rajgopal, Venkatachalam and Kotha (2002) investigate the impact of a broad range of managerial actions on the stock returns of a set of 57 firms engaged in B-to-B e-commerce. They show that the volatility of stock returns is indeed affected by announcements of managerial actions and thereby provide insights on important determinants of stock prices for Internet firms. Using a sample of 46 e-commerce firms during the period 1999-2000, Kotha, Rajgopal and Venkatachalam (2004) investigate the linkage between customers' buying experience, and the firm's competitive advantage as measured by Tobin's q. Customers' confidence in the firm, and relationship services are shown to be positively associated with Tobin's q. Kotha, Rindova and Rothaermel (2001) examine a range of firm specific factors that are associated with a U.S.-based Internet firm's effort to establish a web site in another country. Using a sample of 86 publicly traded firms, they establish that the pursuit of internationalization of these firms is positively related to their reputation and web site traffic as well as to the number of new product and feature announcements and the number of partnership agreements they announced. Put together these and related studies provide important insights into the type of firm which we investigate in this paper. We note that to correct for potential survival bias using Heckman's econometric technique, we would need data on the business models of privately held firms in 
analyze the model, and to complete the survey. Data sources included IPO prospectuses, annual reports, investment analysts' reports, and web sites. The data were collected from May 2000 to June 2001. During that time period, we were able to take one measurement of the design themes for each of the 190 business models in our sample. In other words, we collected cross-sectional data on our independent variables.

We validated inter-rater reliability by assigning a randomly chosen business model to two different raters (each of whom was assigned to a different project manager), and by conducting a pairwise comparison of responses, yielding a Cronbach alpha of 0.81 , and a Pearson correlation coefficient of 0.72 . Raters were in broad agreement with each other for $82 \%$ of the individual items. We repeated the test periodically for different raters and different business models and found that all indicators of reliability had further improved.

\section{Independent Variables}

We selected two independent variables of business model design: efficiency and novelty. We used 13 items as measures of efficiency, and 13 items as measures of novelty. Given the difficulty of obtaining objective measures of business model design, we deemed the use of perceptual measures obtained from our raters appropriate (Dess and Robinson 1984). The strength of each of these items in a given business model was measured using Likert-type scales (see Appendix A for details) and coded into a standardized score. After coding, we aggregated the item scores for each design theme into an overall score for the composite scale using equal weights (see Mendelson 2000). This process yielded distinct quantitative measures of the extent to which each business model in the sample leveraged efficiency and novelty as design themes. (See Table 2 for summary statistics)

We validated the internal consistency and reliability of our measures using standardized Cronbach alpha coefficients, which were 0.69 for the efficiency measure and 0.72 for the novelty measure. Hence, our measures sufficiently satisfy Nunnally's (1978) guidelines, which suggest 0.7 as a benchmark for internal consistency. In order to demonstrate the convergent and discriminant validity of our measures, we ran a Confirmatory Factor Analysis (CFA). We also employed a Partial

order to estimate in the first stage of Heckman's procedure a Probit model of the probability of being a public company. Data limitations, however, prevented us from using Heckman's technique. 
Least Squares (PLS) approach to further strengthen our claim about discriminant validity. The methods and the results are detailed in Appendix B. Both empirical tests provide support for construct validity of our measures.

\section{Dependent Variables}

A firm's stock-market value reflects the market's expectations of future cash flows to shareholders, and hence can be viewed as a measure of perceived venture performance. This differs from realized performance, which is typically embodied in historical measures of firm profitability (e.g., ROI, ROA). Given the level of uncertainty often associated with the true prospects of entrepreneurial firms, perceived performance operationalized as stock market value is a measure that is particularly suitable for an entrepreneurship setting (Stuart, Hoang and Hybels 1999). Measures of realized performance such as ROI, ROA, or Tobin's q are less appropriate for young, high-growth entrepreneurial firms that often have negative earnings, few tangible assets, and low (even negative) book values. For instance, 134 firms in our sample (i.e., $86 \%$ of the sample firms for which we had the relevant accounting data) had negative earnings in Q4 1999. Five firms (i.e., 3\% of the sample firms for which we had the relevant data) even had a negative book value in the same period. These numbers did not change substantially in Q4 2000.

We note the limitations of using stock-market valuation as a dependent variable. The nature of our sample and the period in which we collected the data could give rise to concerns about bias due to an irrational bubble in the stock market. However, while the rationality of the markets during the 1999-2000 period remains an open question (e.g., Pastor and Veronesi 2004 offer a rational explanation for investors' behavior and provide empirical evidence against the bubble hypothesis), our paper is not predicated on the efficiency of capital markets; it rather centers on the differential performance implications of alternative business model designs; our estimation method exploits their differential valuation by capital markets. Even if the companies in our sample were systemmatically overvalued, we believe that one cannot expect the results of our regression analysis to be distorted (i.e., pointing in the wrong direction). Arguing in favor of our methodology, in addition, is the fact that our dependent variable captures the sensitivity to market participants' perceptions of the business cycle, and thus to the level of perceived resource munificence in the environment; it reflects the 
factors that market participants value (akin to Shleifer and Vishny's (1991) analysis of stock market valuations of conglomerates in the 1960s and 1980s). This was actually beneficial for our analysis as it allowed us to test our contingency hypotheses about the moderating effect of resource munificence on the relationship between business model design and firm performance.

Since most firms in our sample have relatively low levels of debt, the market value of a firm's equity is a good approximation of the market value of the whole firm. We measured the market value of equity at a given date as the number of shares outstanding multiplied by the firm's stock price, taken from the combined CRSP and Datastream databases. We then calculated the logarithm of the market value of the equity in order to comply with the normality assumption of Ordinary Least Squares (OLS) regression. Following this transformation, we found that the null hypothesis of normality could not be rejected at the $5 \%$ level of significance using a Shapiro-Wilk test. To test our hypotheses, we used measurements of the dependent variable at various points in time (annual average, average during the fourth quarter (Q4), and the last day of trading of Q4) and in various time periods $(1999,2000)$ characterized by different levels of resource munificence for entrepreneurial firms. We did not have time-series data on our independent variables; therefore, we could not pool the data, introduce a year dummy 2000 and test the hypothesized interaction effect directly, for example through a random effects panel data specification.

Most empirical research has hitherto employed industry-type measures of munificence, such as mean annual industry sales growth (Tushman and Anderson 1986), employment growth in the industry (Dess and Beard 1984), and other indicators of growth at the industry level (McArthur and Nystrom 1991). Because the business model construct spans industry boundaries and many of the sample firms span multiple industries, we could not define an industry-level variable that captured resource munificence adequately. We therefore measured the dependent variables in time periods that were sufficiently distinct in terms of environmental resource munificence yet close to the point in time when the independent variables were measured.

We note that despite the short window, the change in the resource availability for entrepreneurial firms triggered by the worldwide crash of high-tech stocks in March 2000 was severe. Park and Mezias (2003), for example, demonstrate the sharp and statistically significant reversal in a 
number of munificence measures. Table 1 summarizes the differences between the time periods we considered. The year 1999 (and Q4 1999 in particular) was a time of relatively high munificence for entrepreneurial firms in our sample, whereas the year 2000 (and Q4 2000 in particular) was a time of relatively low munificence. In addition, other indicators of environmental uncertainty, such as complexity and dynamism (Dess and Beard 1984), may have changed between the years, perhaps to a lesser extent.

$$
\text { INSERT TABLE } 1 \text { ABOUT HERE }
$$

The use of multiple measures of the dependent variable provided a robustness check for our results. In our analysis, we contrast the average market value of firms in Q4 1999 with that in Q4 2000 , the market value of firms at the close of Q4 1999 with that at the close of Q4 2000, and the average market value of firms in 1999 with that in 2000.

\section{Control Variables}

We included further factors that might influence the market value of a firm's equity as control variables in the analysis because their omission might confound the analysis. Our industry controls were the level of competitive threat, and estimated market size. Our raters measured competitive threat on a four-point Likert scale based on information found in annual reports, prospectuses, competitors' SEC documents and web sites, Forrester benchmark studies, Hoovers' database (which lists each focal firm's main competitors), and investment analysts' reports. The information on market size was obtained from Forrester research reports and from the U.S. Department of Commerce. Consistent with market power arguments (Porter 1980), and with the theory presented in this paper, the greater level of competition that a business model is facing (in more competitive or smaller markets), the lower the chances that the business model will create much total value, and the lower the performance of the focal firm will be.

Our firm-level controls included age of the firm, size, country of origin, and expenditures on R\&D, advertising, and capital. Size was measured as the logarithm of the number of employees. The variable can be viewed as a proxy for the focal firm's bargaining power, relative to rival firms and other business model stakeholders. Ceteris paribus, the larger the focal firm, the greater its potential 
for value creation as well as its bargaining power, and, hence, the better its performance. We controlled for country of origin using a dummy variable (" 1 " for firms headquartered in North America, " 0 " for European firms). The inclusion of these firm-level variables strengthens the claim that our analysis captures the influence of distinct business model design characteristics on firm performance as opposed to the effects of firm characteristics or strategy. For example, investment in R\&D has been used in prior research as a proxy for technology strategy (Dowling and McGee 1994) and also as a proxy for the degree to which a firm pursues a product differentiation strategy (Mizik and Jacobson 2003). Moreover, advertising expenditures have been employed as a proxy for a firm's marketing strategy (Mizik and Jacobson 2003).

Finally, we considered alternative business model design themes, such as complementarities and lock-in (Amit and Zott 2001), by constructing two latent control variables, using nine indicators for complementarities (Cronbach alpha $=0.70)$, and 15 indicators for lock-in (Cronbach alpha $=0.74)$.

\section{Econometric Modeling and Estimation Approach}

We analyzed the data using multivariate regression techniques. We tested the robustness and validity of our model specification in several distinct ways. First, we tested for multicollinearity among independent variables by calculating Variance Inflation Factors (VIF) (see Kleinbaum, Kupper, Muller and Nizam 1998). Second, we performed analyses using different dependent variables. Third, we discarded influential observations from our data set based on established criteria for identifying influential points (e.g., leverage, studentized residual, or change in the determinant of the covariance matrix) to see whether they distorted results. Fourth, we tested for over-fitting of the data. Over-fitting occurs when the fit of the model with the data is due to the idiosyncrasy of a specific data set, not the fundamental relations among the variables. To see whether this was the case in our study, we first took a random subsample of 150 firms, with the remaining firms constituting the holdout sample. We then calibrated the model based on the subsample, and applied the resulting parameter estimates to the holdout sample, calculating goodness-of-fit, pseudo F-value, and Theil U statistic. Fifth, we considered the potential bias introduced by sampling on the dependent variable by running a truncated regression model (Maddala 1986). Sixth, we tested for homoskedasticity using White's test. Seventh, we tested for potential endogeneity (i.e., the concern that business model design 
could be a choice variable that is correlated with unobservables that are relegated to the error term) by running a 2 SLS regression with instrumental variables and by using the Hausmann test (see Appendix C).

None of these basic tests gave rise to concern. Yet, we observed multicollinearity in those regressions where the interaction term between novelty and efficiency was included. We therefore mean-centered the interaction variable, as well as the novelty and efficiency measures (see Aiken and West 1991). This significantly reduced the VIF to levels that attenuated the concern about multicollinearity. In addition, we ensured that the mean-centering approach did not entail a lack of invariance of regression coefficients, which may arise in equations containing interactions even under simple linear transformations of the data (Aiken and West 1991). Overall, therefore, we conclude that our model specification proved robust and valid.

\section{RESULTS}

\section{Descriptive Statistics}

Table 2, Panel A provides an overview of the data set we assembled. It reveals the entrepreneurial nature of our sample firms as well as the enormous change that occurred in the environment between Q4 1999 and Q4 2000. Specifically, in 1999 the median age of a sample company was just over 4 years old, while the mean company was just under 7 years old. The few older firms in the sample are ones that went through an extensive transformation with entrepreneurial management leading the change. The median sales of sample companies in 1999 were just under $\$ 25$ million, while the median book value of equity in 1999 was $\$ 57$ million. The median sample company employed 269 people (mean 1,067). With respect to the change in the environment between 1999 and 2000 , we note that the median company was worth $\$ 349$ million at the end of December 1999 , but only $\$ 49$ million at the end of December 2000 , representing a decline of $85.6 \%$ in market value over a 12 month period.

\section{INSERT TABLE 2 Panel A ABOUT HERE}

Table 2, Panel B depicts the Pearson Correlations among the right-hand side variables used in the regression analysis. We note that while some correlations among the explanatory variables are 
significant, they do not pose a multicollinearity problem as their Variance Inflation Factors (VIF) are low.

\section{INSERT TABLE 2 Panel B ABOUT HERE}

\section{Hypotheses Tested}

Table 3 depicts the OLS regression results. Panels A and B ("full sample") show the results for regressions in which the dependent variable is the logarithm of market value averaged over the fourth quarter of 1999 (Panel A), and 2000 (Panel B). Panel C summarizes the main regression results for each of the three dependent variables we considered. Panel D ("restricted sample") depicts the results of the same regressions reported in Panels A and B on a restricted sample of firms that were present in both 1999 and 2000. In other words, in the regressions reported in Panel D we control for entry to and exit from our sample between 1999 and 2000.

\section{INSERT TABLE 3 Panels A, B, C AND D ABOUT HERE}

Hypothesis 1 (regarding novelty-centered business model design) is supported by the analysis. As depicted by Table 3 (Panels A-D), the coefficient on the novelty variable is positive, and in most cases it is significant both during a period of environmental munificence and during a period of resource scarcity. The observed effect was thus relatively robust to changes in the environment. Our results suggest that even in times of resource scarcity and less uncertainty about the viability of business model designs, innovative business model designs were associated with higher levels of performance.

Comparing Panels A and B (full sample) with panel D (restricted sample), we note that the coefficient on the novelty variable is significant at the $1 \%$ level in the restricted sample for all four models (see Panel D), while it is significant at the $10 \%$ level in the full sample for three of the four models we ran (see Panels A \& B). This might suggest a weakening of the novelty effect due to entry dynamics. We explored these apparent differences by running a separate set of regressions using only those 30 firms that entered our sample in $2000^{3}$. We observed that in most models the coefficients for novelty-centered business model design were not significant for this small set of 30 firms. That is, the 
novelty-centered business model design of the firms that entered our sample in 2000 did not significantly explain the variance in the dependent variable. Furthermore, according to the t-test suggested by Cohen and Cohen (1983, p. 111) the coefficient on novelty in the sample of the 30 entering firms was significantly different from the respective coefficient in the sample in 1999.

This analysis highlights the potential role of entry dynamics for the hypothesized contingent effect of munificence on the relationship between business model design and firm performance. Specifically, under conditions of low resource munificence, capital markets may be less receptive to new public offerings of firms that center their value proposition on novel business models. Overall, however, Hypothesis 2 about the changing strength of the novelty coefficient in different environments receives little support from our data. Following Gatignon (2003), we examined the moderating role of environmental munificence by conducting a Chow test for the equality of the coefficients in the overall model between the 1999 and 2000 regressions. The test provided significant results (see Table 4). This led us to further examine whether the coefficient on novelty caused the observed structural break, which is suggested by Table 3 Panel C. The table shows that the regression coefficients on the novelty variable were highly significant in 1999, and less significant in 2000 . We attempted to confirm whether this effect was statistically significant by conducting a series of pooled regression runs (for all models and all dependent variables) (a) on a completely unrestricted model, in which we included a year dummy ( 0 for 1999,1 for 2000) which we interacted with all variables, (b) on a partially restricted model, in which the only difference with the model in (a) was that the coefficient on novelty-centered business model design was restricted to be the same for 1999 and 2000. Then, we proceeded to do F-tests to test the null hypothesis of homogeneity of the coefficient on novelty in models (a) and (b). Following Gatignon (2003:74) the test statistic we used was [(PRSS - CUSS)/(DF_PR - DF_CU)] / [CUSS / DF_CU], where PRSS was the sum of squared residuals from the partially restricted model, CUSS was the sum of squared residuals from the completely unrestricted model, DF_PR was the number of degrees of freedom of the partially restricted model,

These regressions are not depicted in the paper due to space constraints, but are available from the authors. 
and DF_CU was the number of degrees of freedom of the completely unrestricted model. As a result of these tests, we could not reject the null.

\section{INSERT TABLE 4 ABOUT HERE}

Hypothesis 3 (regarding efficiency-centered business model design) receives mixed support from our data. The results in Table 3 indicate that Hypothesis 3 is supported by the Q4 2000 results in the full sample (Panel B: Models 1-4). The results are robust across all dependent variables (see Panel C). In our full sample, during a period of resource scarcity, entrepreneurial firms performed better if their business model design, and hence value proposition to their customers, partners, and suppliers, included efficiency enhancements that reduced their operating costs, simplified transactions, sped up processes, and generally enhanced the utilization of capital equipment. This enabled companies to capture economies of scale and scope. However, we find that Hypothesis 3 is not supported by the data pertaining to Q4 1999. Table 3 Panel A, which depicts the regression results during a period of environmental munificence (1999), shows that while the coefficient of the mean-centered efficiency index is positive, it is not significant. That is, during this period of abundant resources, efficiencycentered business model design did not serve to differentiate significantly among entrepreneurial firms.

We also note the lack of support that this hypothesis receives from the regressions done on the restricted sample (see Table 3 Panel D). The coefficient on efficiency is insignificant in the restricted sample for each of the models we ran, yet, as noted above, it is significant in the full sample for Q4 2000. What accounts for the difference? Again, we probed deeper into the underlying reasons by running a separate set of regressions using only those 30 firms that entered the sample in 2000 . We observed that these firms have significant positive coefficients for efficiency-centered business model design in 2000 , which were also significantly different from the respective coefficients in the restricted sample in 1999 (according to the t-test suggested by Cohen and Cohen (1983, p. 111)). This may have strengthened the efficiency effect in the full sample.

Regarding the hypothesized contingent effect of environmental munificence, the above analysis highlights the role of entry dynamics. Specifically, under low resource munificence, capital 
markets may be more receptive to new public offerings of firms that promise lower costs. This in turn may favor the IPOs of firms that have more efficiency-centered business model designs. Overall, however, we find that Hypothesis 4 receives little support from our empirical analysis. While the Chow Test suggests a structural break in the overall model parameters between 1999 and 2000 (see Table 4), and while Table 3 Panel C suggests a strengthening of the efficiency effect from 1999 to 2000 , a series of pooled regression analyses with dummy variables (see also Gatignon 2003, p. 74) did not allow us to reject the null hypothesis that the coefficient on efficiency was identical in 1999 and 2000.

Hypothesis 5 regarding the interaction effect among the design themes of business models received no support from the empirical analysis: none of our regressions revealed a significant positive interaction. Indeed, the coefficient of the variable capturing the interaction between novelty and efficiency had a negative sign in all the regressions we ran, yet it was not statistically significant in most cases (see Table 3, Panels A, B, and D). That coefficient, however, was significant at the $10 \%$ level in Model 4 for the full sample when we used our other two dependent variables, namely the logarithm of the market value of firms at the close of Q4 2000, and the logarithm of the average market value of firms in 2000 . For these models we performed post-hoc analysis using plotting techniques suggested by Aiken and West (1991). The plots of efficiency on the respective dependent variable for different values of novelty revealed that for higher values of novelty, the slope of the plotted regression line was smaller, but remained positive. In other words, the plot was consistent with Hypothesis 6 , and yielded the additional insight that while diseconomies of scope in design might exist, they do not override the positive effects of efficiency-centered design on performance. Our analysis of novelty-centered design yielded analogous results. In other words, our data seem to suggest, yet do not convincingly prove, that there appear to be diseconomies of scope in design. That is, on average, attempting to emphasize both efficiency and novelty in the design of a business model may be costly; it adversely affects performance. Our analysis therefore provides preliminary, albeit statistically weak, support for Hypothesis 6. 


\section{DISCUSSION AND CONCLUSION}

The central thesis anchoring our study is the notion that organizational design should extend beyond internal design (Nystrom and Starbuck 1981) to include a focus on the architecture of the transactions that a focal firm engineers with its partners, suppliers, and customers. Consistent with Foss (2002), we suggest the need to pay greater attention to the structuring of firm boundaries and, in particular, to the structuring of a firm's exchanges with external stakeholders. Specifically, we develop a theory of business model design that explains how value is created at the business model level of analysis and how it is captured at the focal firm level of analysis. No prior theory explicitly centered on this issue has existed. Our contribution is the model that links business model design to performance of entrepreneurial firms under varying conditions of environmental munificence.

Although the design of the business model has been raised as an important issue for research on new organizational forms and boundary-spanning organizational designs (Foss, 2002; Rindova and Kotha, 2001), it has not been explored in detail. Perhaps this is because, until now, we lacked a methodology for conceptualizing and measuring business model design with a high degree of granularity. Our methodological contribution is that we provide a way to think about, and measure business model design themes. By moving beyond generic typologies of business models (which are often only applicable to e-commerce firms), we offer a greater level of abstraction and higher degree of granularity in the description and measurement of business model designs. This allows us to outline the design elements of business models that are relevant for wealth creation, and it also allows us to provide measures that can be more generally applied to entrepreneurial firms.

Indeed, our research is particularly relevant to the study of new organizational forms, innovation, and entrepreneurship (e.g., Amit and Zott 2001, Chesbrough and Rosenbloom 2002, Hargadorn and Douglas 2001, Mendelson 2000, Miles and Snow 1986). We operationalize and measure the business model construct, and show empirically that it has impact on wealth creation. To the best of our knowledge, this is the first rigorous empirical large-sample study of business model design themes. While there are promising empirical studies in this domain (e.g., Rajgopal et al. 2003), to our knowledge, there exists no systematic, large-scale, empirical analysis of the performance implications of business model design themes under various environmental regimes. We show that 
capturing configuration as variables, as suggested by Miller (1996), helps us characterize and measure business model designs, which should facilitate further research in that domain.

By providing common definitions for new organizational forms, particularly boundaryspanning organizations, our study can enable comparisons among different designs. It can also help bridge the increasing chasm between the reality of organization design and organization theory that some scholars have asserted (e.g., Daft and Lewin 1993, Ilinitch et al. 1996). Indeed, while organization scholars have identified and investigated cases of new organizational forms, such as the dynamic network form (Miles and Snow 1986), the virtual corporation (Davidow and Malone 1992), or hypertext organizations (Nonaka and Takeuchi 1995), research on these designs could be unified and advanced through common frameworks, concepts, and theories (Daft and Lewin 1993, Foss 2002).

This paper not only articulates essential features and properties of boundary-spanning organizational designs, but it also addresses their performance implications. Our strongest and most robust finding relates to the novelty theme of business model design. That theme centers on innovation, which is "the specific instrument of entrepreneurship. It is the act that endows resources with a new capacity to create wealth" (Drucker 1985, p. 30). Such wealth-creating innovation may be achieved through a recombination of existing resources (Schumpeter 1934) in new designs. Our study shows that firms are not only able to innovate by recombining the resources they control, but also by harnessing those of the partners, suppliers, and customers who participate in their business model. In this way, our study contributes to the entrepreneurship literature. We highlight business model design as a crucial task for entrepreneurs, and as a source of innovation.

We also find that environmental munificence does not moderate the positive relationship between business model design innovation and focal firm performance. This counterintuitive finding is noteworthy. It attests to the remarkable temporal stability of that relationship, thus emphasizing the business model as an important and enduring locus of innovation and wealth creation.

By framing business model design as an entrepreneurial task and by identifying business model innovation as a source of wealth creation for firms, our work informs research at the intersection of organization theory, entrepreneurship, and strategy (Hitt, Ireland, Camp, and Sexton, 
2001). Business model-specific effects may explain some hitherto unexplained variance in the performance of firms; in this sense, they complement, but do not replace, firm-specific and industryspecific effects on firm performance (Rumelt 1991, Hawawini, Subramanian and Verdin. 2003, McGahan and Porter 2002). We also corroborate the premise that in a highly interconnected world, entrepreneurs should consider looking beyond firm and industry boundaries in order to create and capture business opportunities. They can create wealth by introducing innovative boundary-spanning organization designs.

We acknowledge several limitations of this study. Some empirical results could be affected by measurement problems. For example, our measurement of business model design themes may not have captured all lines of a firm's business that have revenue potential; hence, it might not explain all the variation in the dependent variable. Another problem could be that bad management corrupts inherently good designs. Unfortunately, our data do not allow us to control for the quality of management. As well, data limitations do not allow us to engage in a dynamic analysis of businessmodel evolution or to measure value creation at the business-model level directly. Lastly, the scope of the theory presented in this paper, as well as the data set used to test it do not allow us to draw generalizeable conclusions about the role of business model designs in the broader population of firms.

Viewed through an entrepreneurial lens, however, the limitations of this study could present interesting opportunities for future research. For example, do our results apply to more mature and established organizations? Our study also raises questions such as what are the factors that give rise to and shape business model designs? How do regulations, customer preferences, and competition influence the emergence and evolution of these designs? What are the dynamics of business model design change, and how stable are business model designs across time? How reliable is the impact on performance of various business model design themes, and do efficiency-centered business models have higher reliability of performance than novelty-centered ones (Sorensen 2002, Sorenson and Sorensen 2001)? Of specific interest to organization scholars might be the questions of how the firm's architecture of boundary-spanning transactions is linked to its internal organization and how the interaction of the two affects firm performance. Strategy scholars, meanwhile, could be interested in 
the questions of whether and how business model design contributes to the competitive advantage of firms, and whether and how it interacts with firm strategies, such as product market positioning.

It is our hope that the ideas presented in this paper inspire and enable further research on these intriguing issues. We believe that the perspective of the business model, its design elements, and the concepts developed in this paper for describing and measuring business model design themes are a step toward an improved understanding of boundary-spanning organizational designs. 


\section{REFERENCES}

Aiken, L.S., S.G. West. 1991 (Paperback 1996). Multiple Regression: Testing and Interpreting Interactions. Sage, Thousand Oaks, CA.

Aldrich, H.E. 1979. Organizations and Environments. Prentice Hall, Englewood Cliffs, NJ.

Aldrich, H.E. 1999. Organizations Evolving. Sage, Thousand Oaks, CA.

Amit, R., C. Zott. 2001. Value creation in e-business. Strategic Management J. 22 493-520.

Bhide, A. 2000. The Origin and Evolution of New Businesses. Oxford University Press, New York.

Brandenburger, A.M., H. Stuart. 1996. Value-based business strategy. J. Econom. \& Management Strategy 5 5-25.

Bresnahan, T., E. Brynjolfsson, L. Hitt. 2002. Information technology, workplace organization, and the demand for skilled labor: Firm-level evidence. Quart. J. Econom. 117 339-376.

Brynjolfsson, E., L. Hitt. 2004. Intangible assets and the economic impact of computers. W. Dutton, B. Kahin, R. O'Callaghan, A. Wyckoff, eds. Transforming Enterprise. MIT Press, Boston, MA, pp. $27-48$.

Campa, J. M., S. Keida. 2002. Explaining the diversification discount. Journal of Finance LVII 17311762 .

Chesbrough, H., R. Rosenbloom. 2002. The role of the business model in capturing value from innovation: Evidence from Xerox Corporation's technology spinoff companies. Indust. and Corporate Change 11 529-555.

Christensen, C.M. 2001. The past and future of competitive advantage. MIT Sloan Management Rev. 42 105-109.

Clemons, E.K., M.C. Row. 1992. Information technology and industrial cooperation: The changing economics of coordination and ownership. J. Management Inform. Systems 9 9-28.

Coff, R.L. 1999. When competitive advantage doesn't lead to performance: The resource-based view and stakeholder bargaining power. Organ. Sci. 10 119-133.

Cohen, J., P. Cohen. 1983. Applied Multiple Regression: Correlation Analysis for the Behavioral Sciences, 2nd ed. Lawrence Erlbaum Associates, Hillsdale, NJ.

Daft, R.L., A.Y. Lewin. 1993. Where are the theories for the "new" organizational forms? An editorial essay. Organ. Sci. 4 i - vi.

Daft, R.L. 2004. Organization Theory and Design. $8^{\text {th }}$ ed. Thomson South-Western, Mason, OH.

Davidow, W.H., M.S. Malone. 1992. The Virtual Corporation: Structuring and Revitalizing the Corporation for the $21^{\text {st }}$ Century. HarperBusiness, New York.

Deephouse, D.L. 1999. To be different, or to be the same? It's a question (and theory) of strategic balance. Strategic Management J. 20 147-166.

Dess, G.G., D.W. Beard. 1984. Dimensions of organizational task environments. Admin. Sci. Quart. 29 52-74. 
Dess, G.G., R. Robinson. 1984. Measuring organizational performance in the absence of objective measures. Strategic Management J. 5 265-73.

Dowling, M.J., J.E. McGee. 1994. Business and technology strategies and new venture performance: A study of the telecommunications equipment industry. Management Sci. 40 1663-1677.

Drucker, P. 1985. Innovation and Entrepreneurship. Harper \& Row, New York.

Filson, D. 2004. The impact of e-commerce strategies on firm value: Lessons from Amazon.com and its early competitors. J. Bus. 77 135-154.

Fornell, C., D.F. Larcker. 1981. Evaluating structural equation models with unobservable variables and management error. J. Marketing Res. 18 39-50.

Foss, N.J. 2002. Introduction: New organizational forms - critical perspectives. Internat. $J$. the Econom. of Bus. 9 1-8.

Gatignon, H. 2003. Statistical Analysis of Management Data. Kluwer Academic Publishers, Boston, MA.

Gatignon, H., M. Tushman, W. Smith, P. Anderson. 2002. A structural approach to assessing innovation: Construct development of innovation locus, type and characteristics. Management Sci. $\mathbf{4 8}$ $1103-1122$.

Greene, W. 2003. Econometric Analysis. Prentice-Hall, Upper Saddle River, NJ.

Hargadorn, A.B., Y. Douglas. 2001. When innovations meet institutions: Edison and the design of the electric light. Admin. Sci. Quart. 46 476-501.

Hawawini, G., V. Subramanian, P. Verdin. 2003. Is performance driven by industry- or firm-specific factors? A new look at the evidence. Strategic Management J. 24 1-16.

Hite, J M., W.S. Hesterly. 2001. The evolution of firm networks: From emergence to early growth of the firm. Strategic Management J. 22 275-286.

Hitt, M.A., R.D. Ireland, S.M. Camp, D.L. Sexton. 2001. Strategic entrepreneurship: Entrepreneurial strategies for wealth creation. Strategic Management J. 22 479-491.

Hulland, J. 1999. Use of partial least squares (PLS) in strategic management research: A review of four recent studies. Strategic Management J. 20 195-204.

Iansiti, M., K.B. Clark. 1994 Integration and dynamic capability: Evidence from product development in automobiles and mainframe computers. Indust. and Corporate Change 3 557-605.

Ichniowski, C., T.A. Kochan, D. Levine, C. Olson, G. Strauss. 1996. What works at work: Overview and assessment. Indust. Relations 35 299-333.

Ilinitch, A.Y., R.A. D'Aveni, A.Y. Lewin. 1996. New organizational forms and strategies for managing in hypercompetitive environments. Organ. Sci. 7 211-220.

Ireland, R.D., M.A. Hitt, M. Camp, D.L. Sexton. 2001. Integrating entrepreneurship and strategic management actions to create firm wealth. Acad. of Management Executive 15 49-63.

Kaplan, S. N., B.A. Sensoy, P. Stromberg. 2005. What are firms? Evolution from birth to public companies. Working Paper, University of Chicago, Chicago, IL. 
Kleinbaum, D.G., L.L. Kupper, K.E. Muller, A. Nizam. 1998. Applied Regression Analysis and Other Multivariable Methods, $3^{\text {rd }}$ ed. Duxberry Press, Pacific Grove, CA.

Kogut, B. 2000. The network as knowledge: Generative rules and the emergence of structure. Strategic Management J. 21 405-425.

Kotha, S., S. Rajgopal, M.Venkatchalam. 2004. The role of online buying experience as a competitive advantage: Evidence from third party ratings from e-commerce firms. J. Bus. 77 109-133.

Kotha, S., V. Rindova, F. Rothaermel. 2001. Assets and actions: Firm-specific factors in the internationalization of US Internet firms. J. Internat. Bus. Stud. 32 769-791.

Lieberman, M. 2005. Did first-mover advantage survive the dot-com crash? Working paper, UCLA, Los Angeles, CA.

Lee, H., K.G. Smith, C.G. Grimm. 2003. The effect of new product radicality and scope on the extent and speed of innovation diffusion. J. Management 29 753-768.

Lewin, A.Y., H. Volbverda. 1999. Prolegomena on coevolution: A framework for research on strategy and new organizational forms. Organ. Sci. 10 519-534.

MacCormack, A., R. Verganti, M. Iansiti. 2001. Developing products on "Internet time": The anatomy of a flexible development process. Management Sci. 47 133-150.

Maddala, G.S. 1986. Limited-dependent and Qualitative Variables in Econometrics. Cambridge University Press, Cambridge, UK.

Marquis, C. The pressure of the past: Network imprinting in intercorporate communities. Admin. Sci. Quart. 48 655-689.

McArthur, A.W., P.C. Nystrom. 1991. Environmental dynamism, complexity and munificence as moderators of strategy-performance relationships. J. Bus. Res. 23 349-361.

McGahan, A., M. Porter. 2002. What do we know about variance in accounting profitability? Management Sci. 48 834-851.

McGrath, R., I. MacMillan. 2000. The Entrepreneurial Mindset. Harvard Business School Press, Boston, MA.

Mendelson, H. 2000. Organizational architecture and success in the information technology industry. Management Sci. 46 513-529.

Meyer, A D., A.S. Tsui, C.R. Hinings. 1993. Guest co-editors' introduction: Configurational approaches to organizational analysis. Acad. of Management J. 36 1175-1195.

Miles, R.E., C.C. Snow. 1978. Organization Structure, Strategy, and Process. McGraw-Hill, New York.

Miles, R.E., C.C. Snow. 1986. Organizations: New concepts for new forms. California Management Rev. 28 62-73.

Milgrom, P.R., J. Roberts. 1992. Econom., organ. and management. Prentice-Hall, Upper Saddle River, NJ.

Miller, D. 1996. Configurations revisited. Strategic Management J. 17 505-512. 
Mizik, N., R. Jacobson. 2003. Trading off between value creation and value appropriation: The financial implications of shifts in strategic emphasis. J. Marketing 67 63-76.

Nonaka, I., H. Takeuchi. 1995. The Knowledge-Creating Company. Oxford University Press, New York.

Nunnally, J.C. 1978. Psychometric Theory. McGraw-Hill, New York.

Nystrom, P.C., W. H. Starbuck. 1981. Handbook of Organizational Design. Oxford University Press, London.

Park, N.K., J. Mezias. 2005. Before and after the technology sector crash: Stock market response to alliances of e-commerce firms. Strategic Management J. Forthcoming.

Pastor, L., P. Veronesi. 2004. Was there a NASDAQ bubble in the late 1990s? Working paper, University of Chicago, Chicago, IL.

Pfeffer, J., G.R.Salancik. 1978. The Extemal Control of Organizations. Harper \& Row, New York.

Poppo, L., T. Zenger. 1998. Testing alternative theories of the firm: Transaction cost, knowledgebased, and measurement explanations for make-or-buy decisions in information services. Strategic Management J. 19 853-877.

Porter, M.E. 1980. Competitive strategy: Techniques for analyzing industries and competitors. Free Press/Macmillan, New York.

Rajgopal, S., M. Venkatachalam, S. Kohta. 2002. Managerial actions, stock returns, and earnings : The case of business-to-business Internet firms. J. Accounting Res. 40 529-556.

Rajgopal, S., M. Venkatachalam, S. Kotha. 2003. The value relevance of network advantages: The case of e-commerce firms. J. Accounting Res. 41 135-162.

Randolph, W.A., G.G. Dess. 1984. The congruence perspective of organization design: A conceptual model and multivariate research approach. Acad. of Management Rev. 9 114-128.

Reinartz, W., M. Krafft, W. Hoyer. 2004. The CRM process: Its measurement and performance. J. Marketing Res. 41 293-305.

Rindova, V., S. Kotha. 2001. Continuous "morphing": Competing through dynamic capabilities, form, and function. Acad. of Management J. 44 1263-1280.

Romanelli, E. 1991. The evolution of new organizational forms. Annual Rev. of Sociology 17 79-103.

Romme, A.G.L. 2003. Making a difference: Organization as design. Organ. Sci. 14 558-573.

Rumelt, R. 1987. Theory, strategy, and entrepreneurship. D.J. Teece, ed. The Competitive Challenge. Ballinger Publishing Company, Cambridge, MA, 137-158.

Rumelt, R. 1991. How much does industry matter? Strategic Management J. 12 167-185.

Schumpeter, J. A. 1934 (Reprint 1996). The Theory of Economic Development: An Inquiry into Profits, Capital, Credit, Interest, and the Business Cycle. Harvard University Press, Cambridge, MA.

Shleifer, A., R.W. Vishny. 1991. Takeovers in the 60s and the 80s: Evidence and implications. Strategic Management J. 12 51-61. 
Silverman, B. 2001. Organizational economics. J.A.C. Baum, ed. Blackwell Companion to Organizations, Blackwell Publishers, London, 465-493.

Sorensen, J. 2002. The strength of corporate culture and the reliability of firm performance. Admin. Sci. Quart. 47 70-91.

Sorenson, O., J. Sorensen. 2001__Finding the right mix: Franchising, organizational learning, and chain performance. Strategic Management J. 22 713-724.

Stinchcombe, A. 1965. Social structure and organizations. J.G. March, ed. Handbook of Organizations. Rand McNally, Chicago, IL, 142-193.

Stuart, T.E., H. Hoang, R.C. Hybels. 1999. Interorganizational endorsements and the performance of entrepreneurial ventures. Admin. Sci. Quart. 44 315-349.

Thompson, J.D. 1967. Organizations in Action. McGraw-Hill, New York.

Tushman, M.L., P. Anderson. 1986. Technological discontinuities and organizational environments. Admin. Sci. Quart. 31 439-465.

Van de Ven, A., D. Hudson, M. Schroeder. 1984. Designing new business startups: Entrepreneurial, organizational, and ecological considerations. J. Management 10 87-107.

Von Hippel, E., R. Katz. 2002. Shifting innovation to users via toolkits. Management Sci. 48 821-833.

Williamson, O.E. 1975. Markets and Hierarchies -- Analysis and Antitrust Implications. The Free Press, New York.

Williamson, O.E. 1983. Organizational innovation: The transaction cost approach. J. Ronen, ed. Entrepreneurship. Lexington Books, Lexington, MA. 101-133.

Zimmerman, M. A., G. J. Zeitz. 2002. Beyond survival: Achieving new venture growth by building legitimacy. Acad. of Management Rev. 27 414-431.

Zott, C. 2003. Dynamic capabilities and the emergence of intra-industry differential firm performance: Insights from a simulation study. Strategic Management J. 24 97-125.

Zott, C., R. Amit. 2005. Business strategy and business model: Extending the strategy-structureperformance paradigm. Working paper, INSEAD, Fontainebleau, France.

Zott, C., Q. Huy. 2005. Symbolic emphasizing: How entrepreneurs use symbolism to acquire resources. Working paper, INSEAD, Fontainebleau, France. 
APPENDIX A: Survey Items

\begin{tabular}{|c|c|}
\hline \multicolumn{2}{|l|}{ EFFICIENCY-CENTERED BUSINESS MODEL DESIGN } \\
\hline Survey Item & Scale* \\
\hline Inventory costs for participants in the business model are reduced & $\mathrm{SA}, \mathrm{A}, \mathrm{D}, \mathrm{SD}$ \\
\hline Transactions are simple from the user's point of view & $\mathrm{SA}, \mathrm{A}, \mathrm{D}, \mathrm{SD}$ \\
\hline The business model enables a low number of errors in the execution of transactions & $\mathrm{SA}, \mathrm{A}, \mathrm{D}, \mathrm{SD}$ \\
\hline $\begin{array}{l}\text { Costs other than those already mentioned for participants in the business model are reduced (i.e., } \\
\text { marketing and sales costs, transaction processing costs, communication costs, etc.) }\end{array}$ & $\mathrm{SA}, \mathrm{A}, \mathrm{D}, \mathrm{SD}$ \\
\hline The business model is scalable (i.e., can handle small as well as large number of transactions) & $\mathrm{SA}, \mathrm{A}, \mathrm{D}, \mathrm{SD}$ \\
\hline The business model enables participants to make informed decisions & $\mathrm{SA}, \mathrm{A}, \mathrm{D}, \mathrm{SD}$ \\
\hline Transactions are transparent: flows and use of information, services, goods can be verified & $\mathrm{SA}, \mathrm{A}, \mathrm{D}, \mathrm{SD}$ \\
\hline $\begin{array}{l}\text { As part of transactions, information is provided to participants to reduce asymmetric degree of } \\
\text { knowledge amongst them regarding the quality and nature of the goods being exchanged }\end{array}$ & $\mathrm{SA}, \mathrm{A}, \mathrm{D}, \mathrm{SD}$ \\
\hline As part of transactions, information is provided to participants about each other & $\mathrm{SA}, \mathrm{A}, \mathrm{D}, \mathrm{SD}$ \\
\hline Access to large range of products, services and information, and other participants is provided & $\mathrm{SA}, \mathrm{A}, \mathrm{D}, \mathrm{SD}$ \\
\hline The business model enables demand aggregation & $\mathrm{Y}, \mathrm{N}$ \\
\hline The business model enables fast transactions & $\mathrm{SA}, \mathrm{A}, \mathrm{D}, \mathrm{SD}$ \\
\hline The business model, overall, offers high transaction efficiency & $\mathrm{SA}, \mathrm{A}, \mathrm{D}, \mathrm{SD}$ \\
\hline \multicolumn{2}{|l|}{ NOVELTY-CENTERED BUSINESS MODEL DESIGN } \\
\hline Survey Item & Scale* \\
\hline The business model offers new combinations of products, services and information & $\mathrm{SA}, \mathrm{A}, \mathrm{D}, \mathrm{SD}$ \\
\hline The business model brings together new participants & $\mathrm{SA}, \mathrm{A}, \mathrm{D}, \mathrm{SD}$ \\
\hline Incentives offered to participants in transactions are novel & $\mathrm{SA}, \mathrm{A}, \mathrm{D}, \mathrm{SD}$ \\
\hline $\begin{array}{l}\text { The business model gives access to an unprecedented variety and number of participants and/or } \\
\text { goods }\end{array}$ & $\mathrm{SA}, \mathrm{A}, \mathrm{D}, \mathrm{SD}$ \\
\hline The business model links participants to transactions in novel ways & $\mathrm{SA}, \mathrm{A}, \mathrm{D}, \mathrm{SD}$ \\
\hline The richness (i.e., quality and depth) of some of the links between participants is novel & $\mathrm{SA}, \mathrm{A}, \mathrm{D}, \mathrm{SD}$ \\
\hline Number of patents that the focal firm has been awarded for aspects of its business model & $0,1-2,3-4,>4$ \\
\hline Extent to which the business model relies on trade secrets and/or copyrights & $\mathrm{R}, \mathrm{S}, \mathrm{B}, \mathrm{N}$ \\
\hline Does the focal firm claim to be a pioneer with its business model? & $\mathrm{Y}, \mathrm{N}$ \\
\hline The focal firm has continuously introduced innovations in its business model & $\mathrm{SA}, \mathrm{A}, \mathrm{D}, \mathrm{SD}$ \\
\hline There are competing business models with the potential to leapfrog the firm's business model & $\mathrm{SA}, \mathrm{A}, \mathrm{D}, \mathrm{SD}$ \\
\hline There are other important aspects of the business model that make it novel & $\mathrm{SA}, \mathrm{A}, \mathrm{D}, \mathrm{SD}$ \\
\hline Overall, the company's business model is novel & $\mathrm{SA}, \mathrm{A}, \mathrm{D}, \mathrm{SD}$ \\
\hline
\end{tabular}

\section{APPENDIX B \\ Convergent and Discriminant Validity}

We first ran a confirmatory factor analysis (CFA) on a measurement model with two factors, where the efficiency traits loaded onto the efficiency factor, and the novelty traits loaded onto the novelty factor. In this model, the correlation between the efficiency and the novelty index was estimated. We then ran a CFA on a measurement model with only one factor, where the correlation between the efficiency and the novelty variable was constrained to be one. If the model where the correlation is not equal to one improves the fit significantly compared to the constrained model, the two constructs (i.e., novelty and efficiency) are distinct from each other, although they can be significantly correlated (Gatignon et al 2002, Gatignon 2003).

We also used CFA to establish the convergent validity of the constructs, by comparing a measurement model where the correlation between the two constructs was estimated with a model where the correlation was constrained to be equal to zero. "A significant improvement in fit indicates that the two constructs are indeed related, which confirms convergent validity" (Gatignon et al. 2002, p. 1109). 
We used LISREL to implement the CFA, following the routines described in Gatignon (2003, p. 178220). The results from the CFA are displayed in the table below:

\begin{tabular}{|c|c|c|}
\hline Correlation & Chi-squared & Degrees of freedom \\
\hline 0.14 & 733.4 & 319 \\
\hline 0 & 735.1 & 320 \\
\hline 1 & 761.9 & 320 \\
\hline
\end{tabular}

The results from the CFA demonstrate that efficiency-centered design and novelty centered design are two distinct dimensions of business models, although they are positively correlated (estimated correlation $=0.14$ ). This is confirmed by a significantly (at the 0.01 level) improved confirmatory factor analytic model when the correlation is estimated, compared to a measurement model where the correlation is constrained to 1 (chi-squared $=761.9-733.4=28.5$, degrees of freedom $=320-319=$ 1). Furthermore, the results from the CFA demonstrate that efficiency-centered design and noveltycentered design are independent dimensions of business models. The confirmatory factor analytic model when the correlation is estimated, compared to a measurement model where the correlation is constrained to 0 is not significantly improved (chi-squared $=735.1-733.4=1.7$, degrees of freedom $=320-319=1$ ). This is akin to Gatignon et. al's (2002) result that some dimensions of innovation (e.g., competence-enhancing/destroying) are independent of others (e.g., radicalness), yet all measure important, distinct aspects of innovation.

In addition to CFA, the literature suggests partial least squares (PLS) as another method for assessing discriminant validity. Using PLS, one can determine whether a construct shares more variance with its measures than it shares with other constructs in the model (Hulland 1999, Reinartz, et al. 2004). This is achieved by (1) calculating the square roots of the Average Variance Extracted (AVE) values, which measure the average variance shared between a construct and its measures, and by (2) calculating the correlations between different constructs. A matrix can then be constructed where the square root of AVE is in the diagonal, and the correlations between the constructs are in the offdiagonal. For adequate discriminant validity, the diagonal elements should be greater than the offdiagonal elements in the corresponding rows and columns (Fornell and Larcker 1981). In our case, we obtained the following matrix as a result of the PLS analysis. The results further strengthen the discriminant validity of our constructs.

\begin{tabular}{|l|l|l|}
\hline & Efficiency & Novelty \\
\hline Efficiency & 0,233 & 0,175 \\
\hline Novelty & 0,175 & 0,243 \\
\hline
\end{tabular}

Note: (1) The square root of AVE is displayed in the diagonal, and the correlations between the constructs are displayed in the off-diagonal. (2) According to Fornell and Larcker (1981), if the factor variance is set to 1 , then the average variance extracted is defined as: AVE $=\Sigma \lambda_{i}^{2} /\left\{\Sigma \lambda_{i}^{2}+\Sigma\left(1-\lambda_{i}{ }^{2}\right)\right\}$.

\section{APPENDIX C Testing for Endogeneity}

Fundamentally, the concern about endogeneity is about the possibility of reverse causality. To the extent that endogeneity is indeed present in OLS regressions, the standard procedure for dealing with it is to use the Instrumental Variables (IV) technique (a.k.a. two-stage least squares) in cases where the variables that may potentially be endogenous -i.e., in our case NOVELTY \& EFFICIENCY - are continuous (see Greene 2003, pp.398ff). The standard test for endogeneity is the Hausmann Test (see Greene 2003, pp.80ff). The main idea of this test is to see if the estimates of coefficients from OLS are different than the estimate of coefficients from the ones obtained by estimating the model using the IV technique. To the extent that we cannot reject the test's null hypothesis of no endogeneity, then 
there should be less concern about the OLS estimates. If, however, the Haussman test indicates that endogeneity is present, then, for each time period, 1999 and 2000, we must use the appropriate estimation method (e.g., a 2SLS model) to estimate the coefficients. In what follows, we explain the steps that we took in order to run the Hausmann Test.

First, we needed to identify and collect additional data on suitable instrumental variables that satisfied the statistical requirements and were theoretically justifiable. Following the idea that the environment can have an important imprinting effect on organizations (Stinchcombe 1965), our choice was to use munificence variables. ${ }^{4}$ In our study we argue that all firms were subject to the same degree of (high) munificence in 1999 and then subject to the same degree of (low) munificence in 2000. In those two years, then, the degree of munificence could not have affected entrepreneurs' choice of business model designs systematically because all firms faced the same environment. (Yet, munificence interacting with business model design may have well affected investors' perceptions of firm performance, as we argue). Therefore, our challenge was to find suitable munificence measures that could have systematically affected entrepreneurs' choice of business model designs, but not investors' perceptions of performance in 1999 and 2000.

A good instrumental variable possesses two characteristics: (1) It influences the independent variable, and (2) is uncorrelated with the residuals of the regression). ${ }^{5}$ We therefore chose to use time-lagged munificence measures. As there is no prior theory on the determinants of business model designs, we decided to experiment with different time lags:

(a) The year in which the company was founded;

(b) The year in which the company was founded, or 6 years prior to the IPO date, whichever was greater;

(c) The year in which the company was founded, or 3 years prior to the IPO date, whichever was greater.

These choices were based on the following conceptual arguments. The environmental conditions that possibly affected the entrepreneur's early choice of business model design are likely to have an important organizational imprinting effect (see Marquis (2003) for a recent study on how social technologies available at founding continued to influence network structures). If that choice was affected by environmental munificence then one should expect a causal relationship between munificence and business model design. That is why we decided to use the level of munificence in the firm's founding year as our first time-lagged munificence variable (see a).

Some firms in our study, however, are older than the average 7 years for our sample and it might be a stretch to assume that their business models have not changed since they were founded. Thus, at some stage the business model design may have changed, and once again the environmental munificence prevailing at that point in time may have influenced the new design. A recent analysis by Kaplan, Sensoy, and Stromberg (2005) suggests that entrepreneurial firms are surprisingly stable over time. For example, firm business lines remain remarkably stable from business plan through public company, which is a period that, on average, lasted 6 years in the Kaplan et al. (2005) study. Hence, our second choice of a time lag was 6 years prior to the IPO, or the company's birth year, whichever date was greater (i.e., more recent) (see b).

Moreover, all our sample companies had an IPO between 1996 and 2000, and we wanted to acknowledge the possibility that business model designs were less stable than implied by our other two choices. Therefore, our third choice of a time lag was 3 years prior to the IPO, or the company's birth year, whichever date was greater (see c).

\footnotetext{
We would like to thank an anonymous referee for this suggestion.

This requirement for zero or low correlation is difficult to prove empirically. That is part of the reason for why there is no commonly agreed upon scientific method for establishing a good instrument.
} 
The underlying idea behind all these time lags is that the entrepreneur's choice of business model may have indeed been affected by environmental munificence at some point in time prior to the time period of our study. Past munificence measures are less likely to be correlated with residuals from regressions involving as dependent variable firm performance in 1999 or 2000, because investors' perceptions in 1999 or 2000 were probably affected by the prevailing, not past munificence. Hence, these variables conceptually fulfilled the requirements of useful instruments.

Because there were two different variables that we needed to test for endogeneity, EFFICIENCY and NOVELTY, we needed to find two variables--IV1 and IV2--that could have affected business model design. Following Park and Mezias (2005) we have collected additional data from CRSP on the following 22 munificence measures:

- Annual level, relative and absolute annual change in the NASDAQ Index, with pre 1971 data representing the over-the-counter market: 3 variables

- Annual level, relative and absolute annual change in the number of IPOs on NASDAQ, AMEX and NYSE: 9 variables

- Annual level, relative and absolute annual change in \#of firms listed on NASDAQ, Amex, and NYSE that filed for bankruptcy: 9 variables

- Annual US GDP growth: 1 variable

While we have tried to collect data on all these variables for the period 1954 to 2000 , we have some missing observations for some of the variables in the early time period in this new dataset.

Second, we needed to choose instrumental variables from the above list and the control variables in order to perform the first stage of the 2SLS regression. There is no commonly agreed upon and empirically rigorous method for choosing instrumental variables; their choice is often given by theoretical considerations, as well as empirical usefulness (e.g., the IV should meaningfully explain the independent variables); for a recent example of an application of the IV method to control for endogeneity see Campa and Keida (2002).

Given that the choice of suitable instruments for the 2SLS regression is more art than science, we decided to adopt several ways of making this choice.

(a) We selected some munificence variables opportunistically, based on the availability of data (i.e., we preferred variables without any missing observations).

(b) We performed OLS regressions (of the munificence variables on EFFICIENCY and NOVELTY) with stepwise selection of independent variables (using the REG procedure from SAS) and used the retained variables as instruments.

(c) We used all variables retained from (b) as well as all control variables as instruments.

We then estimated the first stage in the 2SLS using the IV form the above lists as follows:

$$
\begin{aligned}
& \text { EFFICIENCY }=b 0+m 1 * I V 1 \text { (IV1 is a vector of instrumental variables) } \\
& \text { NOVELTY }=c 0+m 2 * I V 2 \text { (IV2 is a vector of instrumental variables) }
\end{aligned}
$$

In many cases, the coefficients, $\mathrm{m} 1$ and $\mathrm{m} 2$, were statistically significant, so the instruments indeed explained part of the variation in the business model design themes. The R-squared from the first stage regressions was highest under option (c), for which we found it to be between 0.24 and 0.38 .

In the second stage of the 2SLS procedure, we took the estimated variables from the first stage and plugged them into the main OLS equation, replacing the EFFICIENCY and NOVELTY variables. ${ }^{6}$ We did this for each of our six dependent variables -- the average market value of firms in Q4 1999

6 Technically speaking, we used the MODEL procedure in SAS with the HAUSMAN option to run the OLS and 2SLS regressions with our chosen instruments and to carry out the Hausmann test. 
and in Q4 2000, the market value of firms at the close of Q4 1999 and at the close of Q4 2000, and the average market value of firms in 1999 and in 2000. Together with the permutations explained in steps 1 and 2 above, we thus ran 3 (different time lags) * 3 (different sets of IVs) * 6 (different dependent variables) $=54$ 2SLS regressions, and for each regression we also ran the Hausmann test. ${ }^{7}$ Since this test was never statistically significant (even at the $10 \%$ level), our analyses do not appear to suffer from endogeneity bias.

7 It was actually not necessary to run all these different permutations, because when one uses different instruments (with different R-squares) and one does not find endogeneity with the instrument that has the highest R-squared, then, by definition, one should not find endogeneity when using an instrument that has a lower R-squared. We ran all these regressions anyway, just in order to be on the safe side. 
TABLE 1: Indicators of resource munificence 1999 and 2000

\begin{tabular}{|c|c|c|}
\hline & 1999 & 2000 \\
\hline $\begin{array}{l}\text { Indicators } \\
\text { of } \\
\text { Resource } \\
\text { Munifi- } \\
\text { cence }\end{array}$ & $\begin{array}{l}\text { - Median quarterly sales growth of sample } \\
\text { companies: 30\% (Q2'99), 29\% (Q3'99), } \\
\text { 33\% (Q4 '99) } \\
\text { - Number of Internet-related IPOs in US: } \\
193 \text { (Q4: 62) } \\
\text { - Public market Internet IPO financings in \% } \\
\text { of total IPO financings: } 67 \% \\
\text { - VC funding for B2C e-commerce } \\
\text { companies: \$4.5 billion (+1000\% from } \\
\text { 1998) [1] }\end{array}$ & $\begin{array}{l}\text { - Median sales growth of sample } \\
\text { companies: 18\% (Q1 ’00), 15\% (Q2’00), } \\
8 \%\left(\mathrm{Q}^{\prime} 00\right), 6 \%\left(\mathrm{Q} 4{ }^{\prime} 00\right) \\
\text { - Number of Internet-related IPOs in US: } \\
122(\mathrm{Q} 4: 0) \text { [2] } \\
\text { - Public market Internet IPO financings in } \\
\text { \% of total IPO financings: 36\% [2] } \\
\text { - VC funding for e-commerce companies } \\
\text { dropped from } \$ 843 \text { million (Q1) to } \$ 69 \\
\text { million (Q4) [3] }\end{array}$ \\
\hline
\end{tabular}

Sources: [1] PriceWaterhouseCoopers, http://www.ecommercetimes.com/perl/story/2505.html. [2] Morgan Stanley, "The Technology IPO Yearbook: 8th Edition - 22 Years of Tech Investing," March 2002, http://www.morganstanley.com/institutional/techresearch/ tech ipo yearbook.html?page=research.

[3] PricewaterhouseCoopers/VentureOne,Money Tree Survey Q4 2000.

TABLE 2, Panel A: Descriptive statistics

\begin{tabular}{|l||l|l|l|l|l|l|}
\hline Variable Name (Acronym) & Mean & Median & $\begin{array}{l}\text { Std. } \\
\text { Deviation }\end{array}$ & Min & Max & $\begin{array}{l}\text { No. } \\
\text { Observa- } \\
\text { tions }\end{array}$ \\
\hline $\begin{array}{l}\text { Market Value at Close of Q4 1999 USD } \\
\text { million (MVQtr4Close_99) }\end{array}$ & $\$ 1,506$ & $\$ 349$ & $\$ 3,184$ & $\$ 2$ & $\$ 25,942$ & 159 \\
\hline $\begin{array}{l}\text { Market Value at Close of Q4 2000 USD } \\
\text { million (MVQtr4Close_00) }\end{array}$ & $\$ 387$ & $\$ 49$ & $\$ 1,101$ & $\$ 0.7$ & $\$ 8,885$ & 173 \\
\hline Efficiency & 0.702 & 0.712 & 0.112 & 0.404 & 0.92 & 190 \\
\hline Novelty & 0.366 & 0.359 & 0.133 & 0.077 & 0.795 & 190 \\
\hline Complementarity & 0.617 & 0.639 & 0.174 & 0.000 & 0.972 & 190 \\
\hline Lock-In & 0.454 & 0.463 & 0.140 & 0.167 & 0.763 & 190 \\
\hline Age of firm & 7.0 & 4.3 & 7.8 & 0.4 & 45.8 & 190 \\
\hline Ln number of Employees & 5.723 & 5.593 & 1.336 & 2.833 & 10.342 & 190 \\
\hline Country (1=US, 0=European Country) & 0.88 & 1.00 & 0.32 & 0.00 & 1.00 & 190 \\
\hline R\&D Expense USD 00 (million) & $\$ 2.7$ & $\$ 0.5$ & $\$ 6.4$ & $\$ 0.0$ & $\$ 67.3$ & 190 \\
\hline Advertising expense USD 00 (million) & $\$ 4.7$ & $\$ 1.0$ & $\$ 9.3$ & $\$ 0.0$ & $\$ 52.8$ & 190 \\
\hline Capital Expcnsc USD 00 (million) & $\$ 42.7$ & $\$ 3.7$ & $\$ 415.9$ & $\$ 0.0$ & $\$ 5,733.1$ & 190 \\
\hline Book Value of Equity 99 (million) & $\$ 163.7$ & $\$ 57.3$ & $\$ 416.6$ & $\$-68.6$ & $\$ 4,601.2$ & 188 \\
\hline Book Value of Equity 00 (million) & $\$ 272.8$ & $\$ 71.2$ & $\$ 685.2$ & $\$-967.3$ & $\$ 5,752.2$ & 160 \\
\hline Sales Net USD 99 (million) & $\$ 263.3$ & $\$ 24.9$ & $\$ 1,575.4$ & $\$ 0.0$ & $\$ 20,111.8$ & 177 \\
\hline Sales Net USD 00 (million) & $\$ 331.7$ & $\$ 52.9$ & $\$ 1,643.0$ & $\$ 0.0$ & $\$ 20,609.0$ & 177 \\
\hline Number of Employees & 1,067 & 269 & 3,557 & 17 & 31,000 & 190 \\
\hline Market Size USD 00 (million) & $\$ 20,477$ & $\$ 5,400$ & $\$ 65,640$ & $\$ 120$ & $\$ 744,000$ & 190 \\
\hline
\end{tabular}


TABLE 2, Panel B: Pearson Correlation

\begin{tabular}{|c|c|c|c|c|c|c|c|c|c|c|c|c|c|}
\hline $\begin{array}{l}\text { Variable Name } \\
\text { (Acronym) }\end{array}$ & 总 & 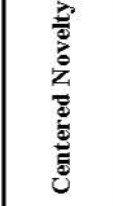 & 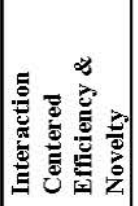 & 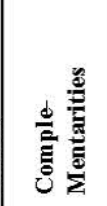 & 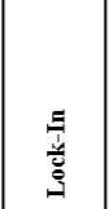 & 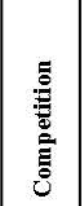 & 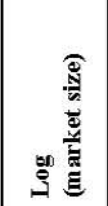 & 落 & 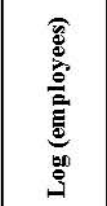 & $\stackrel{B}{E}$ & 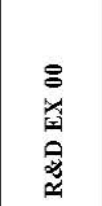 & $\begin{array}{l}8 \\
x \\
z \\
z \\
z\end{array}$ & 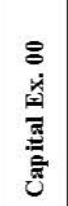 \\
\hline \multicolumn{14}{|l|}{$\begin{array}{l}\text { Independ ent } \\
\text { variables }\end{array}$} \\
\hline Centered efficiency & 1.000 & & & & & & & & & & & & \\
\hline Centered novelty & $0.175^{*}$ & 1.000 & & & & & & & & & & & \\
\hline $\begin{array}{l}\text { Interaction between } \\
\text { centered efficiency } \\
\& \text { centered novelty } \\
\end{array}$ & -0.057 & -0.041 & 1.000 & & & & & & & & & & \\
\hline \multicolumn{14}{|l|}{\begin{tabular}{|l|} 
Control variables \\
\end{tabular}} \\
\hline Complementarity & $0.349^{* * *}$ & $0.349^{* * *}$ & -0.001 & 1.000 & & & & & & & & & \\
\hline Lock-In & $0.316^{* * *}$ & $0.413^{* * *}$ & $-0.173^{*}$ & $0.373 * *$ & 1.000 & & & & & & & & \\
\hline Competition & -0.006 & $-0.322^{* * *}$ & $-0.147^{*}$ & $-0.128^{*}$ & $-0.121^{+}$ & 1.000 & & & & & & & \\
\hline In Market Size & -0.039 & 0.016 & 0.022 & 0.112 & -0.062 & 0.097 & 1.000 & & & & & & \\
\hline Age of firm & -0.112 & $-0.131^{+}$ & 0.118 & $0.026^{*}$ & $-0.152^{*}$ & 0.048 & $0.214^{* * *}$ & 1.000 & & & & & \\
\hline $\begin{array}{l}\text { Ln number of } \\
\text { Employees }\end{array}$ & 0.004 & -0.038 & 0.027 & 0.040 & -0.028 & $\begin{array}{l} \\
0.076 \\
\end{array}$ & $0.338^{* *}$ & $0.452^{* *} \mid$ & 1.000 & & & & \\
\hline Country & -0.074 & $0.168^{*}$ & $0.123^{+}$ & 0.107 & $0.159^{*}$ & 0.097 & $0.462^{* * *}$ & 0.107 & 0.110 & 1.000 & & & \\
\hline R\&D Expense 00 & 0.066 & $0.220^{* * *}$ & 0.049 & 0.088 & $0.140^{+}$ & 0.011 & 0.022 & -0.027 & $0.281^{* * *}$ & $0.123^{+}$ & 1.000 & & \\
\hline $\begin{array}{l}\text { Advertising } \\
\text { expense } 00\end{array}$ & -0.088 & 0.020 & 0.037 & 0.042 & 0.002 & 0.027 & $0.199 * *$ & $0.223^{* * *}$ & $0.493^{* * *}$ & $0.178^{*}$ & $0.434^{\text {***** }}$ & 1.000 & \\
\hline Capital Expense 00 & 0.004 & 0.018 & -0.004 & $0.147^{*}$ & 0.075 & 0.055 & 0.066 & $0.355^{* * *}$ & $0.271^{* * *}$ & 0.036 & $0.001^{*}$ & $0.414^{* * *}$ & 1.000 \\
\hline
\end{tabular}

\begin{tabular}{|c|c|c|c|c|}
\hline \multirow[b]{2}{*}{ RHS Variables } & \multicolumn{4}{|c|}{ Dependent variable Ln (Market Value Quarter 4 Avg 99) } \\
\hline & Model 1 & Model 2 & Model 3 & Model 4 \\
\hline & Estimate (std. error) & Estimate (std. error) & Estimate (std. error) & $\begin{array}{l}\text { Estimate (std. } \\
\text { error) }\end{array}$ \\
\hline Constant & $19.75^{\text {***** }}$ & $17.25^{\text {***ak }}$ & $19.78^{\text {****** }}$ & $17.51^{\text {**:**k }}$ \\
\hline Efficiency & $1.28(1.09)$ & $0.93(0.90)$ & $1.28(1.09)$ & $1.01(0.90)$ \\
\hline Novelty & $3.32^{\text {*kek*k }}(0.93)$ & $2.29^{* * * *}(0.83)$ & $3.21^{\text {*kekek }}(0.93)$ & $2.17^{*}(0.83)$ \\
\hline Interaction Between Efficiency and Novelty & & & $-8.28(7.63)$ & $-9.16(6.09)$ \\
\hline Complementarities & & -0.63 & & -0.59 \\
\hline Lock-In & & 0.80 & & 0.51 \\
\hline Competition & & 0.05 & & -0.08 \\
\hline Log (market size) & & $-0.16^{*}$ & & $0-0.16^{*}$ \\
\hline Age & & 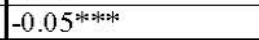 & & $0-0.05^{\text {***** }}$ \\
\hline Log (employees) & & $0.65^{\text {*ak** }}$ & & $0.64^{* * * * * *}$ \\
\hline Country & & 0.12 & & 0.20 \\
\hline R\&D expenditures 1999 & & $0.08^{* * *}$ & & $0.09^{* * * * *}$ \\
\hline Advertising exp. 1999 & & 0.03 & & 0.03 \\
\hline Capital exp. 1999 & & 0.00 & & 0.00 \\
\hline R-squared & 0.10 & 0.52 & 0.11 & 0.53 \\
\hline Adjusted R-squared & 0.09 & 0.48 & 0.09 & 0.49 \\
\hline F & $8.47^{\text {*s*k** }}$ & $13.27^{\text {******* }}$ & $6.04^{\text {*k*k** }}$ & $12.53^{\text {**sk** }}$ \\
\hline $\mathrm{N}$ & 158 & 158 & 158 & 158 \\
\hline
\end{tabular}


TABLE 3, Panel B : Mean centered OLS regression results (full sample)

\begin{tabular}{|c|c|c|c|c|}
\hline \multirow[b]{2}{*}{ RHS Variables } & \multicolumn{4}{|c|}{ Dependent variable Ln (Market Value Quarter 4 Avg 00) } \\
\hline & Model 1 & Model 2 & Model 3 & Model 4 \\
\hline & Estimate (std. error) & Estimate (std. error) & Estimate (std. error) & $\begin{array}{l}\text { Estimate (std. } \\
\text { error) }\end{array}$ \\
\hline Constant & $18.42^{\text {*e*k* }}$ & $16.36^{\text {sk*k* }}$ & $18.44^{\text {*216*k }}$ & $16.64^{\text {**2***3 }}$ \\
\hline Efficiency & $2.21^{\dagger}(1.18)$ & $2.44^{*}(1.01)$ & $2.16^{\dagger}(1.10)$ & $2.51^{*}(1.01)$ \\
\hline Novelty & $1.72^{\dagger}(1.01)$ & $1.54^{\dagger}(0.93)$ & $1.70^{\dagger}(1.01)$ & $1.47(0.93)$ \\
\hline Interaction Between Efficiency and Novelty & & & $-8.24(8.45)$ & $-10.25(6.83)$ \\
\hline Complementarities & & -0.71 & & -0.67 \\
\hline Lock-In & & -0.30 & & -0.57 \\
\hline Competition & & $0.88^{\dagger}$ & & $-1.04^{*}$ \\
\hline Log (market size) & & 0.04 & & 0.04 \\
\hline Age & & -0.01 & & -0.01 \\
\hline Log (employees) & & $0.66^{\text {*2*ksk }}$ & & $0.65^{\text {*sksk }}$ \\
\hline Country & & $-1.12^{* *}$ & & $-1.01^{* * * k}$ \\
\hline R\&D expenditures 2000 & & $0.05^{* * *}$ & & $0.05^{* * *}$ \\
\hline Advertising exp. 2000 & & 0.02 & & 0.02 \\
\hline Capital exp. 2000 & & 0.00 & & 0.00 \\
\hline R-squared & 0.04 & 0.47 & 0.05 & 0.48 \\
\hline Adjusted R-squared & 0.03 & 0.44 & 0.03 & 0.44 \\
\hline $\mathrm{F}$ & $3.84 *$ & $12.59^{\text {*k*k* }}$ & $2.88^{*}$ & $11.88^{\text {*s*kek }}$ \\
\hline $\mathrm{N}$ & 180 & 180 & 180 & 180 \\
\hline
\end{tabular}

TABLE 3, Panel C: Summary of main regression results for different dependent variables

\begin{tabular}{|l|l|l|l|l|l|l|}
\hline & INDEPENDENT VARIABLE & DEPENDENT VARIABLE & MODEL 1 & MODEL 2 & MODEL 3 & MODEL 4 \\
\hline 1999 & Efficiency & Market Value Quarter 4 Close & 1.70 & 1.35 & 1.70 & 1.44 \\
\hline & & Market Value Quarter 4 Average & 1.23 & 0.93 & 1.23 & 1.01 \\
\hline & & Market Value Annual Average & 1.25 & 0.89 & 1.25 & 0.96 \\
\hline 2000 & Efficiency & Market Value Quarter 4 Close & $2.76^{*}$ & $3.16^{* * *}$ & $2.70^{*}$ & $3.26^{* * *}$ \\
\hline & & Market Value Quarter 4 Average & $2.19^{\dagger}$ & $2.44^{*}$ & $2.14^{\dagger}$ & $2.51^{*}$ \\
\hline & & Market Value Annual Average & $1.96^{* *}$ & $1.82^{*}$ & $1.88^{\dagger}$ & $1.87^{*}$ \\
\hline 1999 & Novelty & Market Value Quarter 4 Close & $3.44^{* * * *}$ & $2.61^{* * *}$ & $3.34^{* * * *}$ & $2.49^{* * *}$ \\
\hline & & Market Value Quarter 4 Average & $3.25^{* * * * *}$ & $2.29^{* * *}$ & $3.14^{* * * *}$ & $2.17^{*}$ \\
\hline & & Market Value Annual Average & $2.70^{* * *}$ & $2.00^{*}$ & $2.62^{* * *}$ & $1.89^{*}$ \\
\hline 2000 & Novelty & Market Value Quarter 4 Close & 1.28 & $1.77^{\dagger}$ & 1.23 & 1.66 \\
\hline & & Market Value Quarter 4 Average & $1.69^{\dagger}$ & $1.54^{\dagger}$ & $1.67^{\dagger}$ & 1.47 \\
\hline & & Market Value Annual Average & $2.33^{* * *}$ & $1.93^{*}$ & $2.30^{* * *}$ & $1.85^{*}$ \\
\hline
\end{tabular}




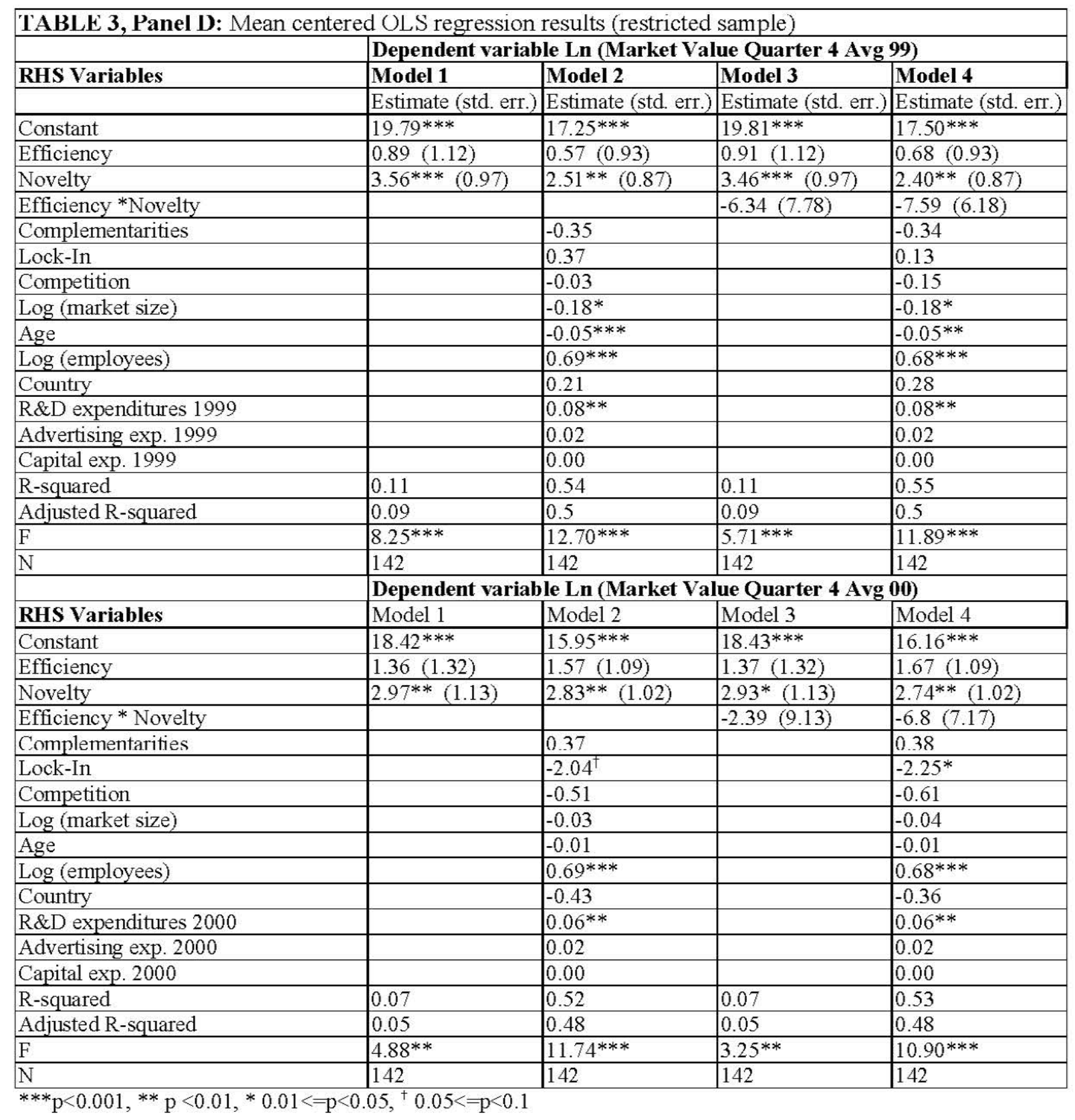

TABLE 4: Chow test for structural break between 1999 and 2000

\begin{tabular}{||l|l|l|l|l|}
\hline DEPENDENT VARIABLE & MODEL 1 & MODEL 2 & MODEL 3 & MODEL 4 \\
\hline Market Value Quarter 4 Close & $34.1^{* *}$ & $14.92^{* *}$ & $25.69^{* *}$ & $14.06^{* *}$ \\
\hline Market Value Quarter 4 Average & $18.3^{* *}$ & $9.1^{* *}$ & $13.81^{* *}$ & $8.6^{* *}$ \\
\hline Market Value Annual Average & $2.48^{\dagger}$ & $1.93^{*}$ & 1.95 & $1.87^{*}$ \\
\hline
\end{tabular}

Table entries are F Statistics. $* * * p<0.01, * 0.01<=\mathrm{p}<0.05,+0.05<=\mathrm{p}<0.1$ 